\title{
Systemic Importance of Insurance Companies-An Empirical Analysis
}

\author{
Anushri Bansal \\ Senior Economist, Research and Innovation Center, Willis Towers Watson, Mumbai, India \\ E-mail: Anushri.Bansal@willistowerswatson.com
}

Received: March 7, 2016

Accepted: March 28, 2016 Published: April 19, 2016

doi:10.5296/ifb.v3i1.9340

URL: http://dx.doi.org/10.5296/ifb.v3i1.9340

\begin{abstract}
Insurance companies are increasingly being regulated under the assumption that, like banks, they pose systemic risk to the overall economy and especially the financial system. This analysis investigates this premise by comparing the systemic importance of insurance companies and the insurance industry with that of banks, brokers, real estate firms, and their respective industries. Empirical results suggest that intra-industry linkages exist among insurance firms, although they are comparatively weaker than those in banking and real estate. Moreover, systemic risks arising from the effects of distress in other economic sectors are lower for insurance companies - although not negligible. Given its size, systemic problems arising over time from the insurance industry would have a very disruptive macroeconomic impact.
\end{abstract}

Keywords: Insurance companies, Systemic risk, Banks 


\section{Introduction}

"The risk that the inability of one institution to meet its obligations when due will cause other institutions to be unable to meet their obligations when due. Such a failure may cause significant liquidity or credit problems and, as a result, could threaten the stability of or confidence in markets." (European Central Bank 2004)

The financial crisis of 2007-2009 has brought the insurance industry under the radar of regulatory authorities. Many consider insurance companies as a source of systemic risk (in the conventional banking sense) and believe they should fall under the same regulatory umbrella as banking and other systemically important institutions.

The 2010 Dodd-Frank Wall Street Reform and Consumer Protection Act, a U.S. federal statute, aims to make financial institutions more accountable by imposing stringent regulatory requirements on "systemically important institutions." And according to Dodd-Frank, this includes insurance companies.

This analysis investigates whether U.S. insurance companies pose systemic risk to other sectors in the financial economy at the timescales and magnitude of risks posed by the banking industry. The systemic risks of banks, brokers, insurance companies, and real estate companies in the U.S. financial sector are compared using $\triangle \mathrm{CoVaR}$ (conditional value at risk) methodology by Adrian \& Brunnermeier (2010).

CoVaR is defined as the $\operatorname{VaR}$ (value at risk) (Note 1) of one institution $i$ conditional on the other institution $j$ being in distress. $\triangle$ CoVaR then captures the difference between the CoVaR of institution $i$ when $j$ is in distress and the CoVaR of institution $i$ when $j$ is operating at its median state. The logic behind this measure is that, rather than treating risk in isolation, it is important to capture interdependencies as well as direction of risk.

The analysis categorizes the top U.S. financial firms from October 2002 to April 2011 into four broad sectors: banking, brokerage, insurance, and real estate. These four sectors are defined as the financial system. The analysis calculates the systemic risk of 1) individual companies on their respective industry, and 2) one industry on the others (industry interlinkages). It then measures size effects by dividing the sample into small, medium, and large companies by market capitalization, and capturing the systemic risk of individual companies on their respective industry by size.

While the study covers multiple aspects of systemic risk, its use of traditional analytical techniques has a few shortcomings. It fails to consider the wide range of scenarios that could impact the insurance industry over a longer term. Moreover, it looks at insurance companies as a whole but not at specific business activities. Still, in applying conventional methodology on systemic risk to the insurance industry, there are benefits in being able to directly compare its impact with that of banking and other sectors.

The results show that:

- Systemic risk contribution. If an insurance firm were to collapse, its systemic risk contribution in the worst-case scenario ( 1 percentile) to the insurance sector would be $6.2 \%$, 
compared with risk contributions of $9.1 \%$ from banks and $22.1 \%$ from real estate companies to their respective sectors. Thus, while intra-industry interlinkages are weaker in the insurance sector compared with banks and real estate, the risks are not negligible in absolute terms.

- Size effect. Systemic risk contribution averages $0.85 \%$ for large banks versus $0.69 \%$ for small banks, and $0.63 \%$ for large insurers versus $0.46 \%$ for small insurers. This indicates a positive correlation of firm size to systemic risk.

- Inter-industry interlinkages. If a banking, brokerage, or realestate firm were to undergo distress or crisis, the impact on the insurance industry would be weaker compared with the impact on the other sectors. Nonetheless, in absolute terms, the numbers are not marginal. The findings suggest that, given the existing regulatory framework and current core insurance activities and liability characteristics, the insurance sector is relatively insulated. But we cannot ignore the interdependencies posed by increased financial intermediation and the blurring distinction between insurers and other players in the financial economy.

- Impact on other sectors. If the insurance industry were to undergo similar levels of duress, the impact on other sectors, including banking, would be significant. This could arise longer term through liability changes, such as increased longevity or declining interest rates. It could also happen in the shorter term through a series of catastrophic climate or other claims, such as terrorism and cyber-attack.

The insurance sector faces significant risks in areas such as health, technology, terrorism, and climate change (Faure \& Hartlief, 2003). Moreover, sources of vulnerability are generally exogenous, residing in the macroeconomic environment or arising from non-core insurance activities. These risks differ intrinsically from those faced by banking, and while there is little debate about whether insurance should be properly regulated, its liability profile suggests that regulation intended for banking could have unintended consequences and might be unable to handle a true systemic crisis in insurance.

In the remainder of the paper, Section 2 discusses the literature around calculating systemic risk, and Section 3 looks at the data and methodology. Section 4 provides an empirical analysis, and Section 5 presents the results. Section 6 highlights the nature of insurance-sector risks and how they differ from banking risks, and Section 7 provides the conclusion.

\section{Measuring Systemic Risk}

The literature shows different ways of capturing the systemic risk of financial institutions, ranging from Granger-causality tests and marginal expected shortfall, to $\triangle \mathrm{CoVaR}$ and state-dependent sensitivity VaR (SDSVaR) models. These analyses use share returns and asset correlations to capture interlinkages and forecast risks, and employ stress tests to model volatility and correlations.

Acharya et al. (2010) aim to capture each banking institution's contribution to systemic risk by calculating systemic expected shortfall (SES). They try to "bridge the gap between 
structural and reduced form approaches" and build a model that helps derive an "optimal policy for managing systemic risk." In an empirical study of the 2007-2009 financial crisis, they forecast risks using stress tests, equity returns, and credit default swap spreads employing high-frequency marginal expected shortfall (MES) measures.

Following Acharya et al. (2010), Brownlees \& Engle (2011) propose a measure of systemic risk that "captures the expected capital shortage of a firm given its degree of leverage and MES." Using threshold autoregressive conditional heteroskedasticity (TARCH) and dynamic conditional correlation (DCC) to model volatility and correlations, they rank U.S. financial firms on systemic risk at different stages of the financial crisis.

Billio et al. (2010) propose several econometric measures to capture interlinkages among different financial institutions using principal components analysis and Granger-causality tests. They use equity share returns to examine interdependencies among four sectors: hedge funds, brokers, banks, and insurance companies. They find that, over time, while these sectors have become more interrelated, the impact of one sector on another varies, with the banking and insurance sector saffecting brokers and hedge funds more than the other way round.

In another measure of systemic risk, Huang, Zhou, \& Zhu (2009) capture the "price of insurance against financial distress" with the aim of examining the relationships among the financial sector, the real economy, and government policy. Their analysis measures systemic risk in the banking sector by calculating the "probability of default and asset correlations from CDS spreads and co-movements of equity returns" and then stresstesting using an integrated micro-macro model.

A few analyses have used the $\triangle C o V a R$ methodology of Adrian \& Brunnermeier (2010). Fong et al. (2009) capture systemic interlinkages among local, international, and mainland China banks in Hong Kong using quantile regressions to calculate CoVaR. Adams, Fuss, \& Gropp (2011) extend the CoVaR methodology to include risk spillovers among financial institutions. They calculate the SDSVaR, measuring "size and duration of spillovers" for different market conditions: calm, normal, or volatile. To assess which bank activities contribute to systemic risk, Brunnermeier, Dong, \& Palia (2012) first measure systemic risk using the CoVaR measure of Adrian \& Brunnermeier (2010) and the SES measure of Acharya et al. (2010). They then discover that banks with higher ratios of non-interest income to interest income are larger contributors of systemic risk.

Having given an overview of academic literature on measures of calculating systemic risk, we now look at our own empirical analysis.

\section{Data and Methodology}

The sample includes the top U.S. financial firms (top $75 \%$ by market capitalization as of December 31, 2007) classified under Standard Industrial Classification (SIC) codes 60-67. It covers depository institutions, non-depository institutions, security and commodity brokers, insurance agents and carriers, and real estate and real estate holding/other investment offices. These are classified under four broad industries: banking, brokerage, insurance, and real 
estate. (Note 2) The analysis period spans October 1, 2002 to April 30, 2011, which gives a balanced panel of 252 firms. For these firms, daily share price data (calendar days) is taken from Bloomberg, and weekly share returns are calculated using log returns. Similarly, weekly S\&P 500 returns are calculated using the S\&P 500 total returns index from Bloomberg for the same time period. The control variables in the sample are:

- One-month and three-month daily Treasury rates, U.S. Federal Reserve database

- One-month and three-month repo rates, Bloomberg

- Daily volatility index, U.S. VIX index from Chicago Board Options Exchange website

- 10-year Treasury bond rates and 10-year BAA corporate bonds, Bloomberg

\subsection{Data Cleaning and Organization}

- Daily share price data are converted into weekly return data using log returns. This is done for all firms in the sample as well as for S\&P 500 share price data.

$$
R_{i t}=\log \left(\frac{\text { price }_{t}}{\text { price }_{t-5}}\right)
$$

- Based on SIC classifications, the firms are classified into four sectors using the following mapping:(Note 3)

- Banks: SIC 60 and SIC 61

- Brokers: SIC 62, SIC 6719, SIC 6722, SIC 6794, and SIC 6799

- Insurance: SIC 63 and SIC 64

- $\quad$ Real estate: SIC 65 and SIC 6798

After data cleaning and accounting for missing values, the sample comprises 84 banks, 28 brokers, 66 insurance companies, and 74 real estate companies.

- Financial system returns (returns of all firms in our sample) and industry returns are calculated using the following:

$$
\begin{aligned}
& R_{t}^{\text {System }}=\sum_{i=1}^{N}\left(\left(M k t \operatorname{Cap}_{i, t-1} * R_{i t}\right) /\left(\sum_{i=1}^{N} M k t \operatorname{Cap}_{i, t-1}\right)\right) \\
& R_{t}^{\text {Ind }}=\sum_{i=1, \text { ind }}^{N}\left(\left(M k t \operatorname{Cap}_{i, t-1} * R_{i t}\right) /\left(\sum_{i=1, \text { ind }}^{N} M k t \operatorname{Cap}_{i, t-1}\right)\right)
\end{aligned}
$$

Where, $R_{t}^{\text {System }}$ and $R_{t}^{\text {Ind }}$ are the weekly returns of the financial system and each industry, respectively. Mkt Cap $p_{i, t-1}$ is the one-week lag current market capitalization of each firm $(i=1,2 \ldots N)$, within the financial system or within a particular sector. 
- In order to capture time-varying $\operatorname{VaR}$ and $\operatorname{CoVaR}$, the following quantile regression equations include one-week lagged control (state) variables. Following Brunnermeier, Dong, \& Palia (2012), the control variables are liquidity risk, interest rate risk, term structure, and default risk.

- Liquidity risk is measured as the spread between the three-month Treasury rate and three-month repo rate.

- Volatility is captured through the VIX close price.

- Interest rate risk is measured as the difference between the three-month Treasury rate and its lag value.

- Term structure is the "yield spread between the 10-year Treasury bond rate and three-month Treasury bill rate.” Brunnermeier, Dong, \& Palia (2012).

- Default risk is defined as the "credit spread between the 10-year BAA corporate bond rate and the 10-year Treasury bond rate." Brunnermeier, Dong, \& Palia (2012).

\subsection{Systemic Risk Using Delta CoVaR}

Systemic risk is calculated using the $\triangle \mathrm{CoVaR}$ measure proposed by Adrian \& Brunnermeier (2010). The measure builds on the traditional $V a R$ measure of the risk imposed by a particular firm in distress on other firms, thus capturing the interdependencies and risk spillovers.

\subsubsection{Definitions}

A. $\quad \operatorname{VaR}_{i}^{q}$ is the worst expected loss incurred by firm $i$ over a specific time period with a $\mathrm{q} \%$ confidence level. We use quantile regressions to calculate $V a R_{i}^{q}$ - defined as the potential asset return/loss $\left(R_{i}\right)$ of firm $i$ over a specific period of time at a given quantile level. We consider one five-day calendar week at a $1 \%$ confidence level.

$$
\operatorname{Probability}\left(R_{i} \leq \operatorname{VaR}_{i}^{q}\right)=q
$$

B. $\operatorname{CoVaR}_{i \mid j}^{q}$ is the $\mathrm{VaR}$ of firm $i$ given firm $j$ is in distress at confidence level $q$. According to Brunnermeier, Dong, \& Palia (2012), firm $j$ being in distress means that its loss is at its $\operatorname{VaR}_{j}^{q}$ level. We first calculate $\operatorname{CoVaR}_{i \mid j}^{q}$ at $q=1 \%$ and then calculate $\operatorname{CoVaR}_{i \mid j}^{q}$ at $q=50 \%$; i.e., when firm $j$ is operating at its median (normal) state. Firm $j^{\prime} s$ contribution to systemic risk is defined as the difference between the $V a R$ of firm $i$ when firm $j$ is operating at its $\operatorname{VaR}$ loss levels and the $\operatorname{VaR}$ of firm $i$ when firm $j$ is operating at its median state. 


$$
\text { Systemic risk }=\Delta \operatorname{CoVaR}_{j}^{q}=\operatorname{CoVaR}_{i \mid j}^{q=1 \%}-\operatorname{CoVaR}_{i \mid j}^{q=\text { median }=50 \%}
$$

In order to reach this measure - the contribution of systemic risk of firm jto firm $i$ - the following analysis is done:

- Calculation of $\boldsymbol{V a R}$. Perform quantile regression of the weekly return variable of firm $j$ on control variables at $1 \%$ quantile and at $50 \%$ quantile. Use the fitted values from these regressions to obtain $\operatorname{VaR}$ at $1 \%$ and at $50 \%$.

$$
R_{j, t}^{q}=\alpha_{j, t}^{q}+\beta_{j}^{q} C_{t-1}+\varepsilon_{j}^{q}-\text { where } q=1 \% \text { and } 50 \%
$$

Where $R_{j, t}^{q}$ is the weekly return of firm $j$ at time $t$ at $q \%$ quantile; and $C_{t-1}$ is the vector of control variables, taken at a lag of one week.

Taking the fitted values from the above regression, $\operatorname{VaR}$ is estimated through:

$$
\operatorname{VaR}_{j, t}^{q}=\hat{\alpha}_{j}^{q}+\hat{\beta}_{j}^{q} C_{t-1}-\text { where } q=1 \% \text { and } 50 \%
$$

- Calculation of CoVaR. Run 1\% quantile regression of weekly return of firm $i$ on lagged values of control variables and lag of weekly returns of firm $j$ :

$$
R_{i, t}^{q}=\alpha_{i \mid j, t}^{q}+\beta_{i \mid j}^{q} C_{t-1}+\delta_{i \mid j}^{q} R_{j, t-1}+\varepsilon_{i \mid j}^{q}-\text { where } q=1 \%
$$

Then plug the fitted values from this regression into the following regression to obtain the conditional $\mathrm{VaR}$ for both $\mathrm{q}=1 \%$ and $\mathrm{q}=50 \%$ :

$$
\operatorname{CoVaR}_{i \mid j, t}^{q}=\hat{\alpha}_{i \mid j}^{q}+\hat{\beta}_{i \mid j}^{q} C_{t-1}+\hat{\delta}_{i \mid j}^{q} \operatorname{VaR}_{j, t}^{q}+\varepsilon_{i \mid j}^{q}-\text { where } q=1 \% \text { and } 50 \%
$$

- Calculation of systemic risk. Contribution of systemic risk of firm $j$ to firm $i$ is then calculated using:

$$
\text { Systemic risk }=\Delta \operatorname{CoVaR}_{j, t}^{q}=\operatorname{CoVaR}_{i \mid j, t}^{q=1 \%}-\operatorname{CoVaR}_{i \mid j, t}^{q=\operatorname{median}=50 \%}
$$

- Size effects. Divide the sample into three quantiles - small, medium, and large-by market capitalization as of December 2007 for all companies in the sample and companies within each sector. Then measure the contribution of systemic risk from individual firms to their respective industries, filtered by size.

\section{Empirical Analysis}

The above methodology is used to calculate the contribution of systemic risk for the following: 
- Intra-industry interlinkages - Individual companies on their respective industries, such as a bank's imposition of systemic risk on the banking industry

- Size effects - Contribution of systemic risk of individual firms to their respective industries, filtered by size

- Inter-industry interlinkages - Contribution of risk from one industry to another industry, such as the banking industry's contribution of systemic risk to the insurance industry

\section{Results}

\subsection{Understanding the Sample}

The sample consists of 252 firms in the financial sector: 84 banks, 66 insurance companies, 28 brokers, and 74 real estate firms. Among these firms, average (median) weekly returns for the analysis period (October 1, 2002 to April 30, 2011) were $0.19 \%$ for insurance and $0.12 \%$ for banks, falling to $-0.17 \%$ and $-0.48 \%$ during the crisis period. The Herfindahl index shows that this is a well-diversified sample, with brokers being the most concentrated at $10.4 \%$,followed by insurance companies at $8.2 \%$, banks at $6.3 \%$, and real estate firms at $2.6 \%$, indicating no disproportionate market power or an industry run by only a few.

Table 1. Firm-wise weekly share returns (\%)

\begin{tabular}{|l|l|l|l|l|l|l|l|}
\hline $\begin{array}{l}\text { Firm-wise } \\
\text { weekly share } \\
\text { returns (\%) }\end{array}$ & Time period & 1 percentile & 25 percentile & Median & 75 percentile & 99 percentile & $\begin{array}{l}\text { Standard } \\
\text { deviation }\end{array}$ \\
\hline Banks & $2002-2011$ & -19.73 & -2.08 & 0.12 & 2.23 & 17.82 & 6.75 \\
\hline & $2007-2009$ & -30.10 & -4.66 & -0.48 & 3.62 & 27.01 & 10.57 \\
\hline Insurance & $2002-2011$ & -19.34 & -1.84 & 0.19 & 2.17 & 16.18 & 6.26 \\
\hline & $2007-2009$ & -33.07 & -3.23 & -0.17 & 2.85 & 27.30 & 9.71 \\
\hline Brokers & $2002-2011$ & -18.56 & -2.43 & 0.34 & 3.02 & 16.77 & 7.13 \\
\hline & $2007-2009$ & -27.82 & -4.39 & -0.15 & 4.02 & 23.68 & 11.09 \\
\hline Real estate & $2002-2011$ & -17.73 & -1.93 & 0.38 & 2.46 & 3.35 & 5.90 \\
\hline & $2007-2009$ & -29.62 & -4.29 & -0.20 & 3.79 & 26.02 & 9.51 \\
\hline All firms & $2002-2011$ & -18.93 & -2.01 & 0.23 & 2.36 & 16.61 & 6.43 \\
\hline & $2007-2009$ & -30.39 & -4.12 & -0.27 & 3.49 & 26.34 & 10.11 \\
\hline
\end{tabular}

Source: Author's calculations using Bloomberg data. 


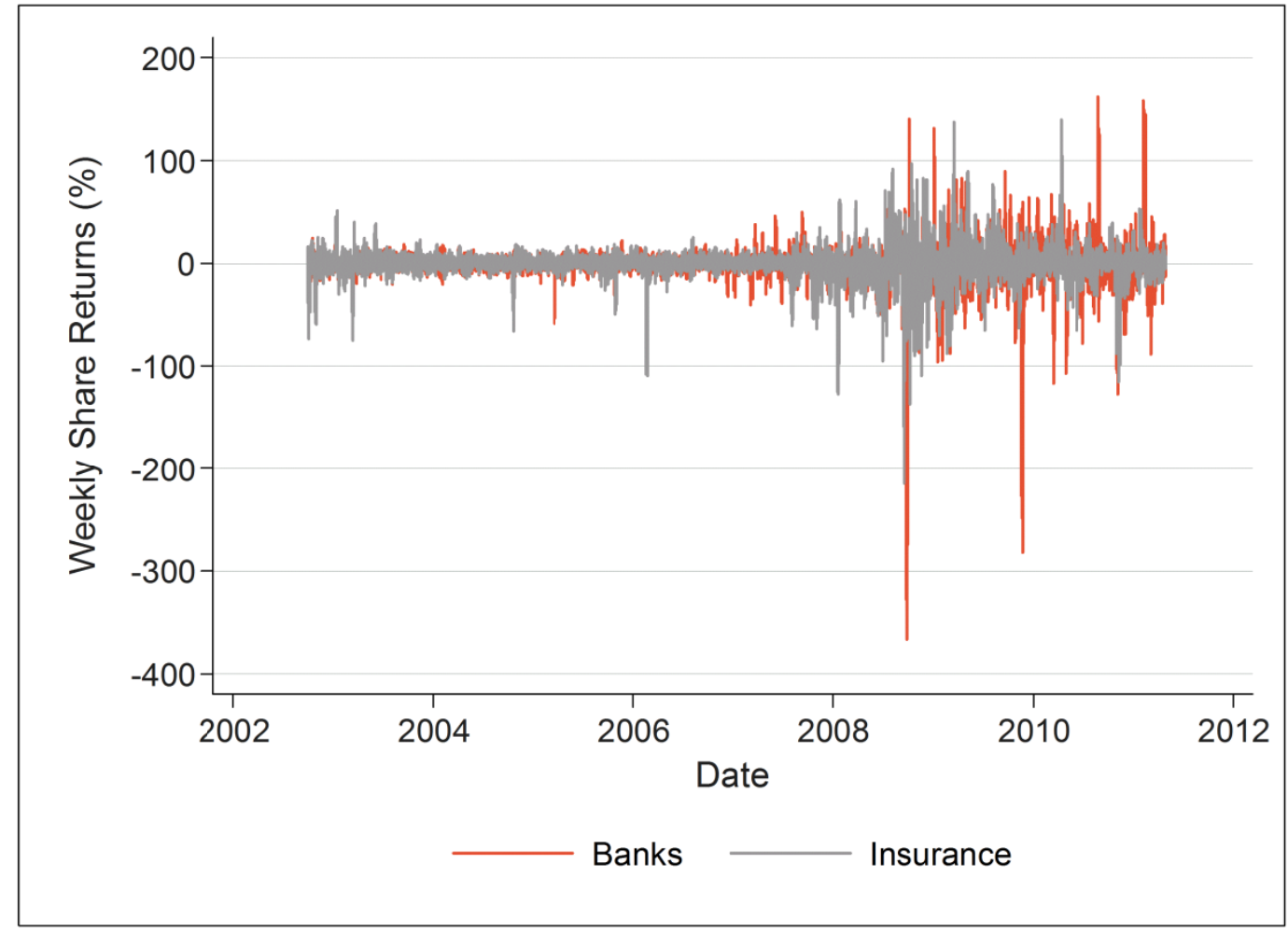

Figure 1. Firm-wise weekly share returns (\%)

Source: Author's calculations using Bloomberg data

Table 2. Firm-wise weekly value at risk (\%)

\begin{tabular}{|l|l|l|l|l|l|l|}
\hline $\begin{array}{l}\text { Firm-wise weekly value } \\
\text { at risk (\%) }\end{array}$ & Time period & 1 percentile & 25 percentile & Median & 75 percentile & 99 percentile \\
\hline Banks & $2002-2011$ & -50.43 & -16.71 & -11.34 & -7.95 & -3.63 \\
\hline & $2007-2009$ & -60.42 & -27.70 & -21.17 & -16.63 & -8.90 \\
\hline Insurance & $2002-2011$ & -55.53 & -17.47 & -11.49 & -8.11 & -3.05 \\
\hline & $2007-2009$ & -75.81 & -31.00 & -22.86 & -16.25 & -6.54 \\
\hline Brokers & $2002-2011$ & -38.08 & -14.47 & -10.77 & -7.54 & -3.62 \\
\hline & $2007-2009$ & -50.95 & -22.52 & -17.01 & -13.01 & -7.02 \\
\hline Real estate & $2002-2011$ & -47.16 & -14.84 & -9.76 & -6.86 & -2.93 \\
\hline & $2007-2009$ & -63.95 & -22.69 & -16.15 & -11.15 & -3.95 \\
\hline All firms & $2002-2011$ & -49.35 & -16.03 & -10.83 & -7.71 & -3.56 \\
\hline & $2007-2009$ & -64.68 & -25.79 & -19.36 & -14.59 & -6.24 \\
\hline
\end{tabular}

Source: Author's calculations using Bloomberg data 


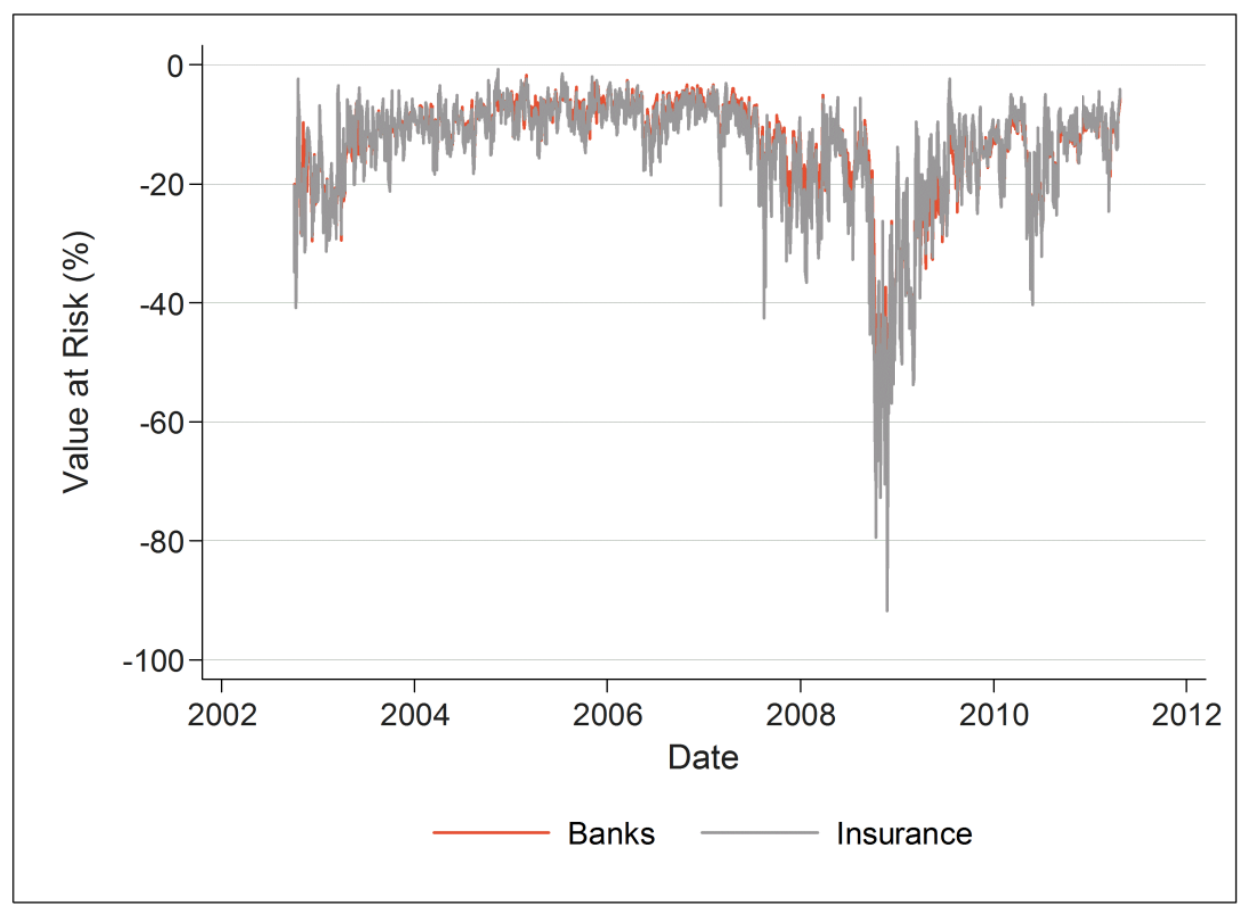

Figure 2. Firm-wise weekly value at risk (\%)

Source: Author's calculations using Bloomberg data

Firm-wise weekly VaR results show that, on average (median levels), returns for banks and insurance firms would fall by around $11 \%$ in a week, and up to roughly $22 \%$ during the crisis period with a confidence level of $99 \%$. As mentioned earlier, VaR measures probable loss levels and does not reflect interlinkages or major correlations, so we consider these results as indicative and move to a more robust measurement of systemic risk through conditional VaR analysis in the next section.

Table 3. Sector-wise weekly share returns (\%)

\begin{tabular}{|l|l|l|l|l|l|l|l|}
\hline $\begin{array}{l}\text { Sector-wise weekly } \\
\text { share returns (\%) }\end{array}$ & Time period & 1 percentile & 25 percentile & Median & 75 percentile & 99 percentile & $\begin{array}{l}\text { Standard } \\
\text { deviation }\end{array}$ \\
\hline Banks & $2002-2011$ & -32.98 & -4.80 & 0.35 & 5.26 & 27.84 & 10.66 \\
\hline & $2007-2009$ & -47.18 & -11.49 & -1.40 & 7.77 & 36.81 & 16.33 \\
\hline Insurance & $2002-2011$ & -19.87 & -2.90 & 0.48 & 3.71 & 13.70 & 6.77 \\
\hline & $2007-2009$ & -29.30 & -6.46 & -0.66 & 4.75 & 19.70 & 10.14 \\
\hline Brokers & $2002-2011$ & -13.79 & -1.78 & 0.45 & 2.35 & 8.83 & 4.23 \\
\hline & $2007-2009$ & -21.59 & -4.43 & -0.22 & 3.68 & 10.77 & 6.32 \\
\hline Real estate & $2002-2011$ & -34.42 & -4.02 & 0.98 & 5.60 & 23.30 & 10.86 \\
\hline & $2007-2009$ & -48.53 & -11.39 & -1.26 & 8.38 & 33.12 & 16.18 \\
\hline
\end{tabular}

Source: Author's calculations using Bloomberg data 
Sector-wise weekly share returns for all sectors fell the furthest during the financial crisis (July 2007 to December 2009). Real estate and banking were the hardest hit, with returns falling as low as $-91.8 \%$ and $-96.5 \%$, respectively, and 1 percentile returns for banking falling to $47.2 \%$. Insurance returns also took a hit, albeit a less severe one, with the lowest being $-73.8 \%$, and 1 percentile returns falling to $-29.3 \%$ during the financial crisis (Table 3 ).

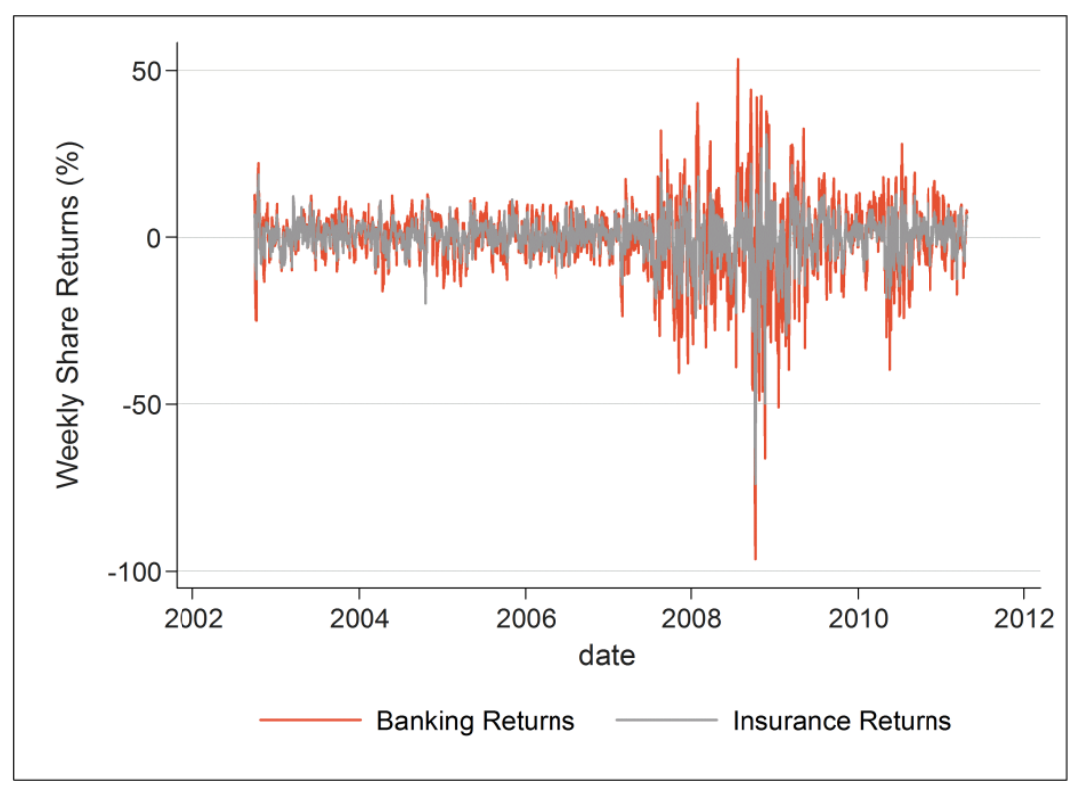

Figure 3. Sector-wise weekly share return (\%)

Source: Author's calculations using Bloomberg data

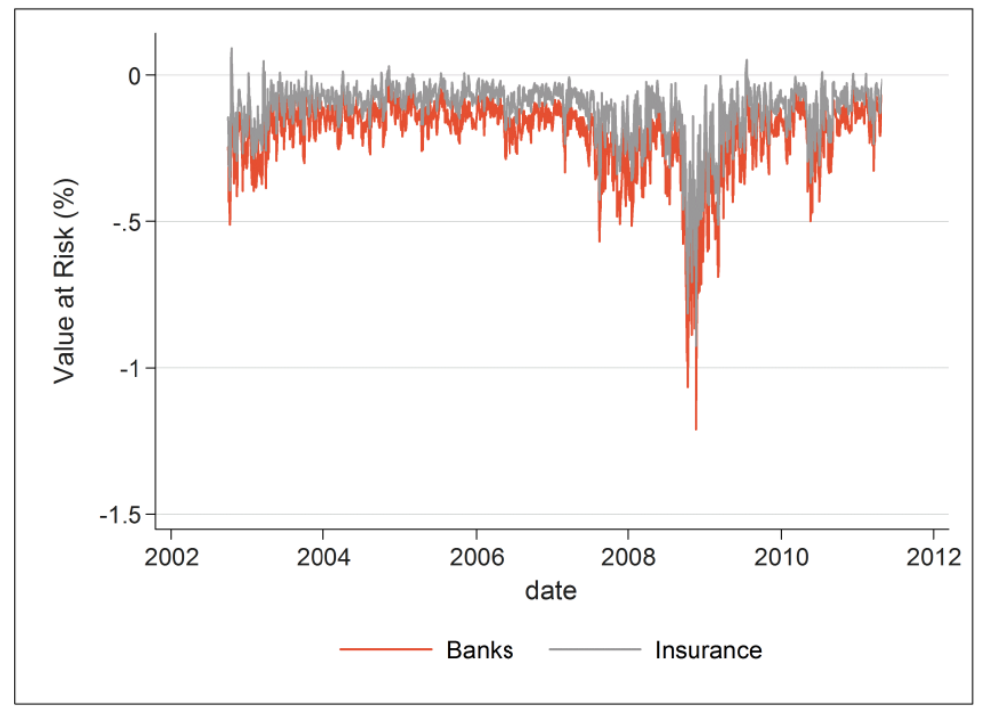

Figure 4. Sector-wise value at risk (\%)

Source: Authors calculations using Bloomberg data 
Looking at these results, one might conclude that the insurance industry was affected as severely as the banking industry during the recent financial crisis, which was triggered by the collapse of the real estate and banking sectors. However, most of the absolute returns were also affected by other macroeconomic risks, like liquidity risk, interest rate risk, term structure, and default risk. With most indicators going negative during the crisis, insurance industry returns were bound to take a hit. To assess the interlinkages between sectors and thus measure systemic risk contribution, we must isolate the impact of one on the other while controlling for other macroeconomic risks.

\subsection{Systemic Risk from Individual Companies to Their Respective Industries}

We now look at the systemic risk imposed by individual companies on their respective industries, which is the risk that a distressed or collapsing firm could harm its entire sector.

Table 4. Systemic risk from individual firm on own industry

\begin{tabular}{|l|l|l|l|l|l|}
\hline $\begin{array}{l}\text { Delta CoVaR, Individual firm } \\
\text { on ownindustry }\end{array}$ & 1 percentile & 25 percentile & Median & 75 percentile & 99 percentile \\
\hline Banks & -0.0914 & -0.0331 & -0.0225 & -0.0160 & -0.0090 \\
\hline Insurance & -0.0618 & -0.0207 & -0.0138 & -0.0103 & -0.0053 \\
\hline Brokers & -0.0149 & -0.0063 & -0.0049 & -0.0042 & -0.0032 \\
\hline Real estate & -0.2210 & -0.0759 & -0.0512 & -0.0380 & -0.0216 \\
\hline
\end{tabular}

Source: Author's calculations using Bloomberg data

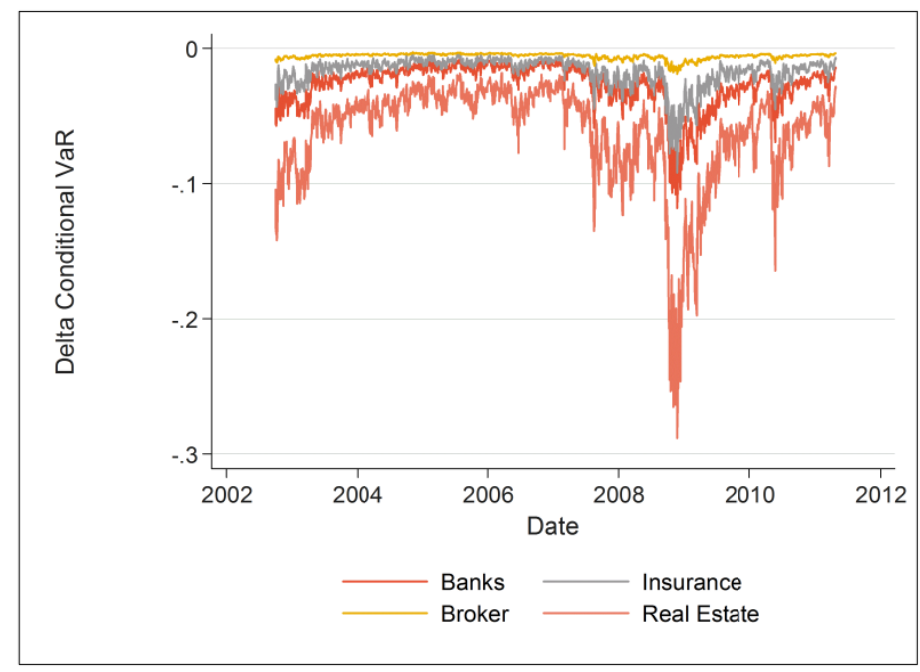

Figure 5. Systemic risk from individual firm on own industry

Source: Author's calculations using Bloomberg data

As reflected in Table 4 and Figure 5, real estate companies are the most systemically risky. In a worst-case scenario, a collapsing real estate firm could impose as much as a $-22.1 \%$ (1 percentile) loss. Banking firms, on the other hand, could impact the banking sector by up to 
$-9.1 \%$, while insurance firms would impact the insurance sector by $-6.2 \%$. Brokerage firms would impact their sector by only $-1.5 \%$.

A collapsed insurance company would have less effect on its overall sector than would real estate and banking companies, but a greater effect than a collapsing brokerage firm, according to these results. Looking at absolute numbers, however, a $-6.2 \%$ impact indicates turbulence, albeit at a lesser degree than in real estate or banking. This suggests that correlations and industry intralinkages within the insurance sector make it vulnerable to failure. The source of these vulnerabilities and their impact may be less pronounced than in real estate and banking, but they do exist.

\subsubsection{Size Effect}

This section aims to capture differences in systemic risk based on firm size. We divide the sample into three quantiles by market capitalization as of December 2007 for firms in each industry, and then measure the contribution of systemic risk from individual firms to their respective industries, filtered by size.

Table 5. Median market capitalization by size across industries

\begin{tabular}{|l|l|l|l|}
\hline $\begin{array}{l}\text { Median market cap. } \\
\text { (USD bn) }\end{array}$ & Small & Medium & Large \\
\hline Banks & 1.22 & 2.69 & 22.10 \\
\hline Insurance & 1.92 & 4.77 & 27.00 \\
\hline Brokers & 2.09 & 6.54 & 29.70 \\
\hline Real estate & 1.16 & 2.57 & 7.29 \\
\hline All firms & 1.30 & 3.28 & 16.20 \\
\hline
\end{tabular}

Source: Author's calculations using Bloomberg data

Table 6. Systemic risk on own industry by firm size

\begin{tabular}{|l|l|l|l|l|}
\hline $\begin{array}{l}\text { Median Delta CoVaR by size of firm (individual } \\
\text { firm on own industry) }\end{array}$ & Small & Medium & Large & All \\
\hline Banks & -0.0069 & -0.0083 & -0.0085 & -0.0225 \\
\hline Insurance & -0.0046 & -0.0061 & -0.0063 & -0.0138 \\
\hline Brokers & -0.0065 & -0.0044 & -0.0020 & -0.0049 \\
\hline Real estate & -0.0159 & -0.0182 & -0.0171 & -0.0512 \\
\hline
\end{tabular}

Source: Author's calculations using Bloomberg data 


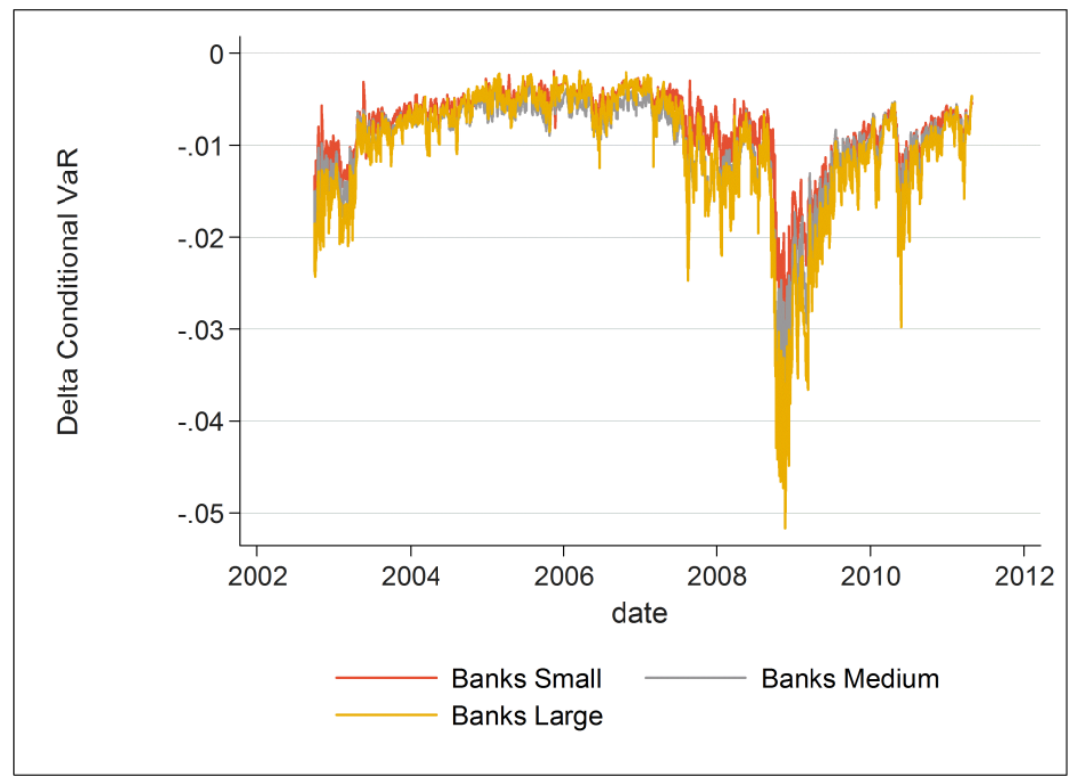

Figure 6. Systemic risk by firm size for banks

Source: Author's calculations using Bloomberg data

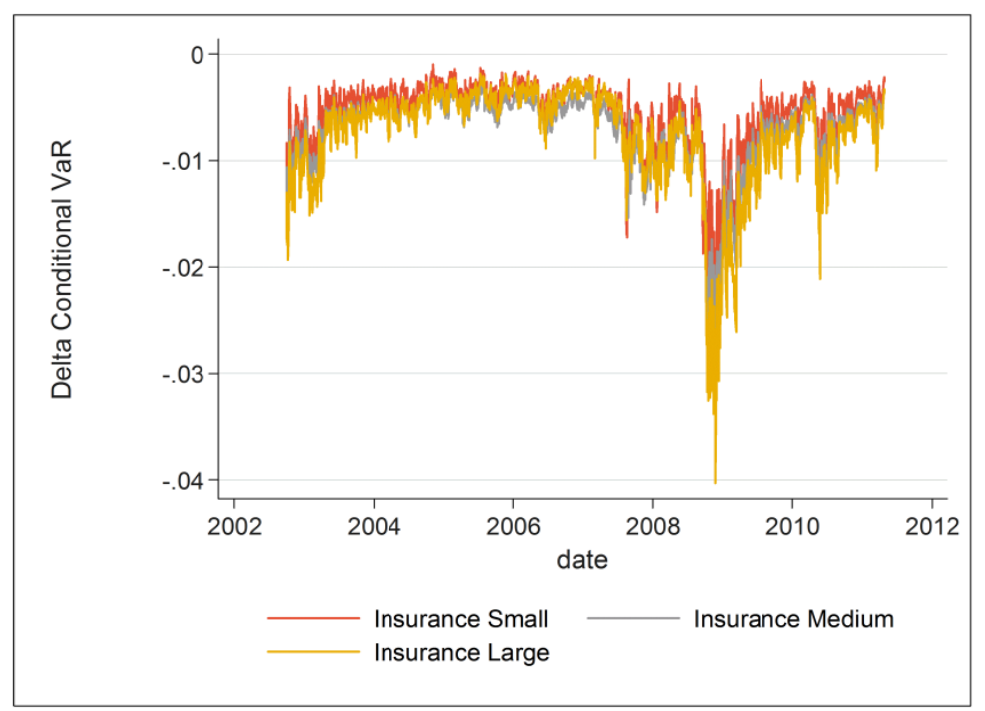

Figure 7. Systemic risk by firm size for insurance

Source: Author's calculations using Bloomberg data

As shown in Table 6, and Figures 6 and 7, systemic risk increases by size for both banks and insurance companies, implying that the larger a company's market capitalization, the higher the systemic risk to its own industry. The systemic risk contribution averages $0.85 \%$ for a large bank compared with $0.69 \%$ for a small bank, and $0.63 \%$ for a large insurance firm versus $0.46 \%$ for a small insurer. These results confirm the assumption that the larger the firm, the greater its risk contribution in the event of distress. 


\subsection{Systemic Risk-Industry Interlinkages}

Having looked at the risk posed by individual firms on their respective sectors, we now look at how the collapse of an entire industry would impact other industries in the financial system.

\subsubsection{Banks as a Source of Distress}

The recent crisis exposed the systemic importance of the banking sector. The interlinkages to the financial system were apparent, with the collapse of Lehman Brothers triggering the collapse of the banking industry, and the ramifications rippling through the U.S. economy and spiraling into a global crisis.

Our analysis shows that, if banking were to collapse, it would have the most severe impact on the banking sector, followed by real estate, insurance, and brokerage. On average (median), the banking sector's systemic risk contribution is $-12.5 \%$ on banking, $-9.8 \%$ on real estate, $-2.4 \%$ on insurance, and $-1.0 \%$ on the brokerage sector.

Of the four sectors in the sample, the insurance sector would suffer less than banking or real estate and only slightly more than brokerage, suggesting some degree of resiliency to a banking sector collapse. Nevertheless, $-2.4 \%$ is not a marginal impact, suggesting interconnectedness between the banking and insurance industries, which could be due to the greater role played by insurance companies in global financial markets, as investors and through financial intermediation. Insurance companies are using capital markets to offload their own risks through financial instruments such as derivatives, credit default swaps, and other risky and complex financial innovations. To some extent, this has blurred the distinction between banks and insurance companies and increased interdependencies (Krennand Oschischnig, 2003).

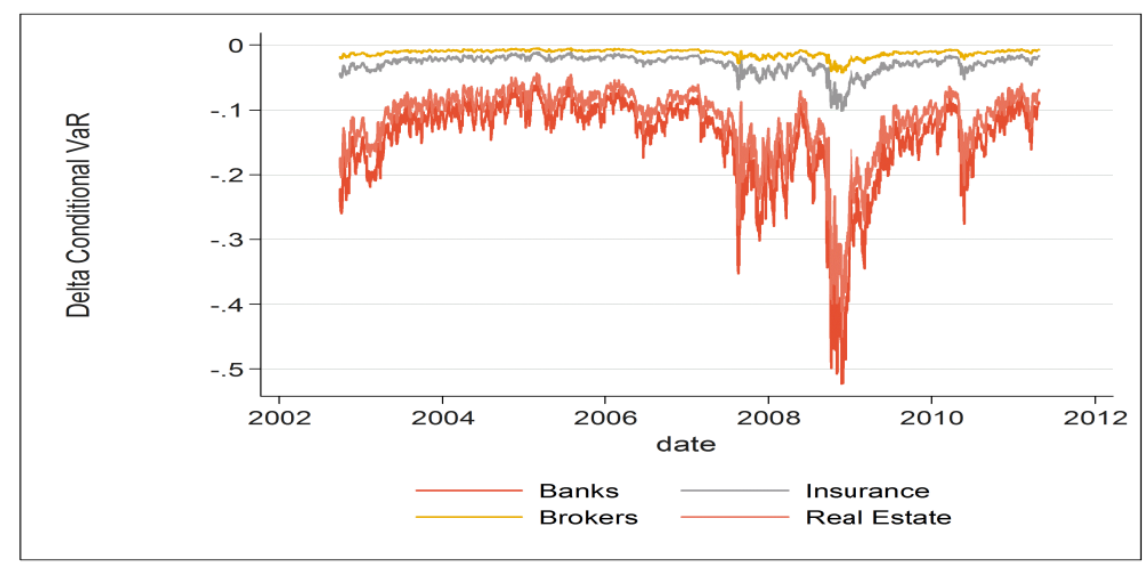

Figure 8. Systemic risk contribution from banking sector

Source: Author's calculations using Bloomberg data 


\subsubsection{Real Estate and Brokers as a Source of Distress}

We next look at the systemic risk contribution of the real estate and brokerage sectors, and estimate the impact on all four sectors - banking, real estate, insurance, and brokerage - if the sector were in distress.

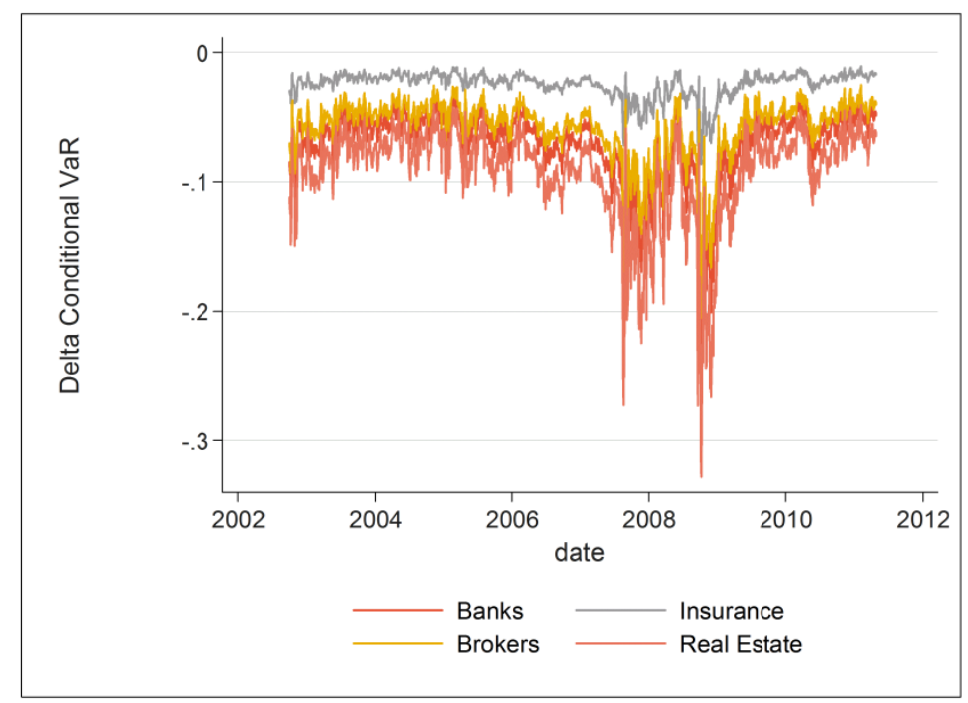

Figure 9. Systemic risk contribution from brokerage sector

Source: Author's calculations using Bloomberg data

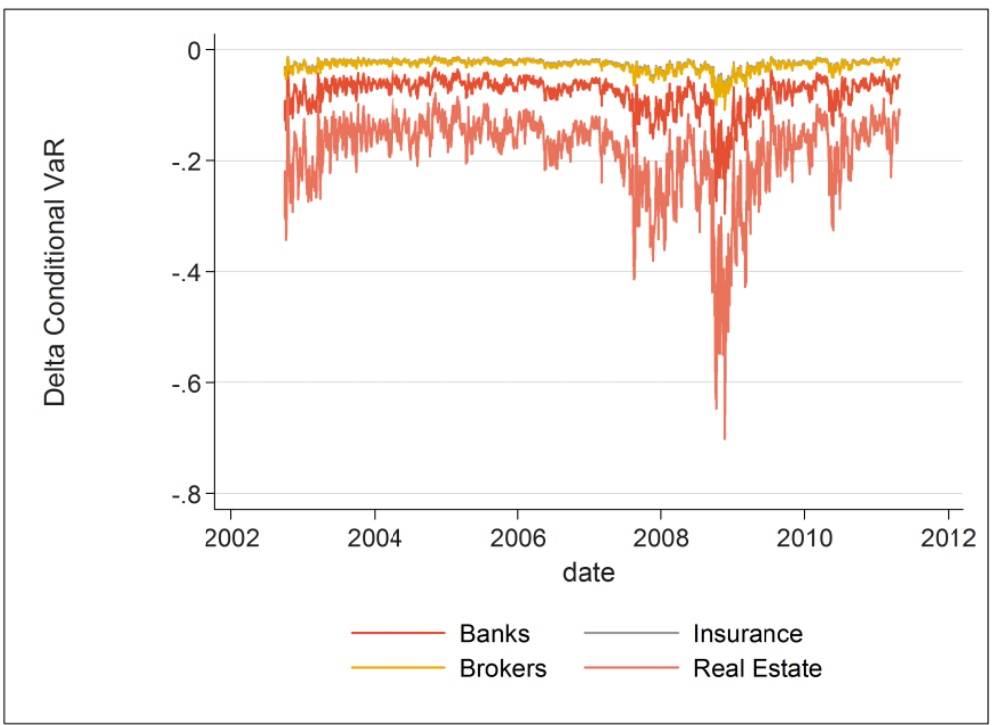

Figure 10. Systemic risk contribution from real estate sector

Source: Author's calculations using Bloomberg data

As shown in Figures 9 and 10, the insurance sector is the least affected by both the brokerage and real estate sectors, with the average systemic risk contributions being $-2.2 \%$ and $-2.3 \%$, respectively. The real estate and banking sectors are again affected most strongly, with the systemic risk contribution from the brokerage sector averaging $-8.3 \%$ for real estate and $-6.3 \%$ 
for banking. The systemic risk contribution from real estate averages $-16.4 \%$ to real estate and $-6.9 \%$ to banking.

Collapses of other sectors would have a smaller impact on the insurance sector than they would have on other industries. In terms of absolute numbers, however, this impact is not insignificant. On the one hand, this result highlights the relative robustness of the insurance regulatory environment, the nature of the insurance business and its risks, and current best practices that help keep the industry resilient. On the other hand, the results also show interlinkages of the insurance sector and risk exposures it shares with other sectors, due to the use of special purpose vehicles (SPVs) and other complex instruments to transfer risk.

The analysis now looks at the outcome of an insurance sector collapse or a crisis arising from the insurance sector.

\subsubsection{Insurance as a Source of Distress}

Table 7. Delta CoVaR-Insurance sector on all sectors

\begin{tabular}{|l|l|l|l|l|l|}
\hline $\begin{array}{l}\text { Delta CoVaR-Insurance on } \\
\text { different industries }\end{array}$ & 1 percentile & 25 percentile & Median & 75 percentile & 99 percentile \\
\hline Banks & -0.4412 & -0.1494 & -0.1044 & -0.0815 & -0.0466 \\
\hline Insurance & -0.3694 & -0.1250 & -0.0874 & -0.0682 & -0.0390 \\
\hline Brokers & -0.1383 & -0.0468 & -0.0327 & -0.0255 & -0.0146 \\
\hline Real estate & -0.2459 & -0.0832 & -0.0582 & -0.0454 & -0.0259 \\
\hline
\end{tabular}

Source: Author's calculations using Bloomberg data

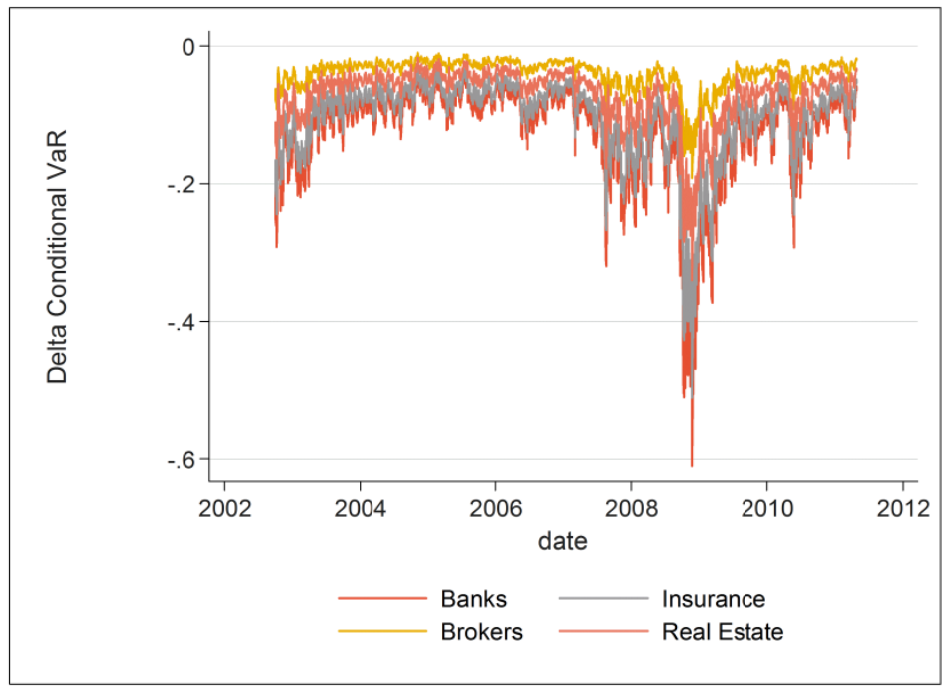

Figure 11. Systemic risk contribution from insurance sector

Source: Author's calculations using Bloomberg data 
Looking at the systemic importance of the insurance industry, Table 7 paints an entirely different picture. If the insurance industry were to collapse, its average systemic risk contribution would be $-10.4 \%,-8.7 \%,-5.8 \%$, and $-3.3 \%$ on banking, insurance, real estate, and brokerage, respectively. This indicates that the collapse of the insurance industry would pose an inherent risk to the financial economy. Some share of these risks could be attributed to the massive and complex interconnections that continue to evolve within the financial system (Schwarcz \& Schwarcz, 2014).

The vulnerability and source of systemic risk for the insurance sector could be through higher liabilities due to increasing longevity and interest rate decline in the longer term, or natural disasters, technology-related disasters, or terrorism in the shorter term.

\section{Characteristics and Key Risks Faced by the Insurance Sector}

The insurance sector faces several risks from the exogenous environment, such as macroeconomic downturns, inflation, low interest rates, unfavorable legislation, terrorist attacks, and natural disasters. It is also vulnerable to long-term risks like global aging, rising health care costs, and climate change. These risks are intrinsically different from those faced by the banking sector, which tend to be shorter term. Insurers have long-term liabilities, which they match with long-term assets (securities). Banks, on the other hand, have short-term liabilities, which they typically match to mostly long-term illiquid assets (loans), thus resulting in liability mismatches and incentives to take credit risks to generate returns.

Insurance companies face both non-financial liabilities - relating to losses in the real economy-and financial liabilities - relating to savings and credit protection products provided by life insurers. The latter are mostly linked to the financial markets and constitute the primary source of vulnerability. However, insurance companies invest mostly in high-quality assets that are marked-to-market (reflecting immediately in the income sheet), while banks hold mostly trading assets. Moreover, reinsurers play an enormous role in insurers' balance sheets. Reinsurance is generally recognized as a reduction in liabilities and is recoverable as an asset. Though reinsurance has been dominated by the non-life market, there has been an increase by the life segment as well (Impavido \& Tower, 2009).

\subsection{Risks Faced by Insurance Companies}

Underwriting risks. These risks arise from the very nature of the insurance industry and are confined to this industry. The underwriting risks faced by the non-life business are more uncertain than those in the life business, since death rates remain relatively stable and predictable. However, natural and man-made disasters could significantly affect death rates, introducing greater uncertainty. Moreover, financial guarantee insurers may exacerbate a financial crisis if the guarantees are backed by risky and complex financial instruments, such as mortgage-backed securities, due to higher counterparty risk. In addition to these risks, operational processes, including calculating premiums, designing products, and selling insurance, could be subject to risks. Several of these risks are transferred through the issuance of bonds, such as catastrophe (CAT) bonds and the creation of SPVs. 
Market risk/investment risk. This risk is associated with the asset side of the balance sheet. Insurance companies invest in bonds, shares, property, loans, and similar vehicles. These investments are affected by changes in interest and exchange rates, political upheaval, and other factors, and thus are subject to market risk. Insurance companies try to mitigate these risks through various regulations, as well as by applying asset liability, VaR, and other models.

Credit risk. This is the risk of a counterparty's defaulting or being unable to meet its obligations. Even where a counterparty can meet its obligations, risks can arise from a downgrade in credit quality due to the economic environment. This impacts the creditworthiness of insurance company investments. Insurance companies should diversify their risks as much as possible.

Reinsurance companies probably face maximum credit risk since most of the risks they insure relate to disasters and other large-scale upheavals. Reinsurers tend to diversify their risks by providing their services to different insurance segments and in different geographical regions.

Liquidity risk. This is the risk of a firm's being unable to meet its liabilities. This might be due to unfavorable market conditions or downgraded credit quality, or be specific to the company. Companies can mitigate liquidity risk through hedging strategies along with asset liability management (ALM).

Given these risks, the primary source of vulnerability is the larger role insurance companies play in global financial markets as investors and through financial intermediation. Moreover, varying insurance regulations across countries along with the insurance sector's limited experience with these new investment tools suggests that the market has little information about the potential impact of these tools on insurance companies, and whether existing market and credit risk management tools are adequate (Krenn \& Oschischnig, 2003).

Off-balance sheet transactions and the use of SPVs and other complex instruments to transfer risk are generally procyclical and subject to economic and macro environment factors. Thus, insurance companies are exposed to external factors as well as to accounting and financial frauds. Moreover, increased reliance on credit rating agencies seemed to backfire in the recent crisis. Another threat to financial sustainability while using alternative instruments to transfer risks could arise from the credit risk associated with most of these financial instruments (Krenn \& Oschischnig, 2003).

In addition to these factors, overlapping roles between banks and insurance companies through financial conglomerates and bancassurance (bank insurance model) channels of distributing insurance increase risks (Krennand Oschischnig, 2003).

\subsection{Management of These Risks}

The key question is how insurance companies manage these risks. While non-life insurance companies bear all the risk (with shareholders bearing both underwriting and investment losses), life insurance companies might be able to share risks. For the latter, the emergence of 
the savings and investment business has created products that are similar to those provided by mutual and other funds, but with a tax advantage. Most of the investment risk associated with these products (e.g., unit linked, market linked) falls on policyholders (Impavido \& Tower 2009).

The Geneva Association recommends focusing on activities rather than entire institutions to understand systemic risk. None of the activities of insurance companies-investment management, liability origination, or capital management-pose direct systemic risk. However, non-core activities - "derivatives trading on non-insurance balance sheets and mismanagement of short term funding from commercial paper or securities lending"-pose systemic risk (The Geneva Association, 2010).

\section{Conclusion}

Using the $\triangle$ CoVaR measure of systemic risk by Adrian \& Brunnermeier (2010), this analysis measures the systemic risk of individual firms on their respective sectors and captures industry interlinkages by estimating the impact of one industry's collapse on the other sectors. Our analysis shows that, while these linkages are considerably more limited in insurance than in banking, they are not negligible. This indicates that, despite protection provided by its regulatory environment, the nature of the risks, and current best practices, insurance firms are vulnerable to increasing interconnectedness through complex financial tools and processes. An insurance sector collapse would harm other sectors in the financial economy, and regulations should be designed to recognize and try to minimize such risks. The probability of an event that could trigger a crisis in the insurance sector is relatively low but, given the nature of the risks and the core practices of an insurer, must be considered a possibility.

This paper looks at insurance companies as a whole rather than at specific business activities. We recognize that, in the shorter term, traditional insurance activities are not systemically risky and vulnerabilities are due to exogenous risks, like natural catastrophes, cyber-attack, and terrorism (Eling \& Pankoke, 2014). Moreover, the risks faced by insurance firms are longer term in nature, such as climate change and global aging, and are mostly triggered by the external environment or activities that are considered non-core to the insurance sector.

Given the different risk profiles confronting banking and insurers, subjecting insurance to the same regulations designed for banking could leave the insurance industry unprotected from other risks of significant macroeconomic impact.

\section{Acknowledgements}

This research is financed by Willis Towers Watson. Am very gratefulto Mike Orszag, Head of Research at Willis Towers Watson, for his support and mentorship.

\section{About Willis Towers Watson}

Willis Towers Watson (NASDAQ: WLTW) is a leading global advisory, broking and solutions company that helps clients around the world turn risk into a path for growth. With roots dating to 1828 , Willis Towers Watson has 39,000 employees in more than 120 countries. We design and deliver solutions that manage risk, optimize benefits, cultivate talent, and 
expand the power of capital to protect and strengthen institutions and individuals. Our unique perspective allows us to see the critical intersections between talent, assets, and ideas - the dynamic formula that drives business performance. Together, we unlock potential. Learn more at willistowerswatson.com.

\section{References}

Acharya, V. V., Pederson, L. H., Philippon, T., \& Richardson, M. P. (2010). Measuring Systemic Risk. AFA 2011 Denver Meetings Paper. http://dx.doi.org/10.1002/9781118258231.ch4

Adams, Z., Fuss, R., \& Gropp, R. (2011). Spillover Effects among Financial Institutions: A State-Dependent Sensitivity Value-at-Risk (SDSVaR) Approach. SSRN. SAFE Working Paper No. 20. http://dx.doi.org/10.1017/S0022109014000325

Adrian, T., \& Brunnermeier, M. K. (2010). CoVaR. Federal Reserve Bank of New York. Staff Reports no.348, Revised.

Adams, Z., Fuss, R., \& Gropp, R. (2011). Basel III and Beyond: Regulating and Supervising Banks in the Post-Crisis Era. Deutsche Bundesbank and the Centre for European Economic Research (ZEW), Eltville, Germany, October 19-20. [Online] Available: http://ftp.zew.de/pub/zew-docs/veranstaltungen/Basel3_Programme.pdf

Bell, M., \& Keller, B. (n.d.). Insurance and Stability: The Reform of Insurance Regulation. Zurich: Zurich Financial Services Group.

Billio, M., Getmansky, M., Lo, A. W., \& Pelizzon, L. (2010). Econometric Measures of Systemic Risk in the Finance and Insurance Sectors. NBER, Working paper no. 16223.

Brownlees, C. T., \& Engle, R. F. (2011). SRISK: A Conditional Capital Shortfall Measure of Systemic Risk. SSRN. http://dx.doi.org/10.2139/ssrn.1611229

Brunnermeier, M. K., Dong, G., \& Palia, D. (2012). Banks’ Non-Interest Income and Systemic Risk. AFA 2012 Chicago Meetings Paper. http://dx.doi.org/10.2139/ssrn.1786738

Das, U. S., Davies, N., \& Podpiera, R. (2003). Insurance and Issues in Financial Soundness. IMF Working Paper no. 03/138. http://dx.doi.org/10.5089/9781451856002.001.

Eling, M., \& Pankoke, D. (2014). Systemic Risk in the Insurance Sector-What do we know? Institute of Insurance Economics, University of St. Gallen, Working papers on risk management and insurance No. 124.

European Central Bank. (2004). Annual Report: 2004. Frankfurt: ECB.

Faure, M. G., \& Hartlief, T. (2003). Insurance and Expanding Systemic Risks. Policy Issues in Insurance, No. 5. Paris: OECD Publishing. 10.1787/9789264102910-en

Fong, T., Fung, L., Lam, L., \& Yu, I. (2009). Measuring the Interdependence of Banks in Hong Kong. Hong Kong Monetary Authority. Working paper no. 19/2009.

Huang, X., Zhou, H., \& Zhu, H. (2009). A Framework for Assessing the Systemic Risk of 
Major Financial Institutions. Journal of Banking and Finance, 33(11), 2036-2049. http://dx.doi.org/10.1016/j.jbankfin.2009.05.017

Impavido, G., \& Tower, I. (2009). How the Financial Crisis Affects Pensions and Insurance and Why the Impacts Matter. IMF Monetary and Capital Markets Department. Working paper no. 09/151.

Krenn, G., \& Oschischnig, U. (2003). Systemic Risk Factors in the Insurance Industry and Methods for Risk Assessment. In G. Thonabauer (ed.), OENB Financial Stability Report, 6, 62-72. Vienna: Oesterreichische Nationalbank. [Online] Available: https://www.oenb.at/

Makinen, G. (2002). The Economic Effects of 9/11: A Retrospective Assessment. Report for Congress. Washington D.C.: Congressional Research Service. The Library of Congress.

Schwarcz, D., \& Schwarcz, S. L. (2014). Regulating Systemic Risk in Insurance. The University of Chicago Law Review, 81, 1569-1640. http://dx.doi.org/10.2139/ssrn.2404492

The Geneva Association. (2010). Systemic Risk in Insurance. An analysis of insurance and financial stability. Special Report of The Geneva Association Systemic Risk Working Group. Geneva: The Geneva Association.

\section{Appendix}

Appendix 1. Company list, industry mapping, and market capitalization (data from Bloomberg)

\begin{tabular}{|l|l|l|l|l|}
\hline Company & BB ticker & $\begin{array}{l}\text { Market cap (as of Dec. } \\
\text { 2007) USD billion }\end{array}$ & SIC code & Industry \\
\hline FNB CORP & FNB US Equity & 0.89 & 6021 & Banks \\
\hline PARK NATL CORP & PRK US Equity & 0.90 & 6021 & Banks \\
\hline UMPQUA HOLDINGS & UMPQ US Equity & 0.92 & 6035 & Banks \\
\hline PAC CAP BANCORP & PCBC US Equity & 0.93 & 6022 & Banks \\
\hline PRIVATEBANCORP & PVTB US Equity & 0.93 & 6022 & Banks \\
\hline OLD NATL BANCORP & ONB US Equity & 0.99 & 6021 & Banks \\
\hline GLACIER BANCORP & GBCI US Equity & 1.00 & 6022 & Banks \\
\hline BOSTON PRIV FINL & BPFH US Equity & 1.00 & 6022 & Banks \\
\hline MB FINANCIAL & MBFI US Equity & 1.10 & 6035 & Banks \\
\hline LAURENTIAN BANK & LB CN Equity & 1.10 & 6029 & Banks \\
\hline CITIZENS REPUBLI & CRBC US Equity & 1.10 & 6021 & Banks \\
\hline PACWEST BANCORP & PACW US Equity & 1.20 & 6021 & Banks \\
\hline HANCOCK HLDG CO & HBHC US Equity & 1.20 & 6022 & Banks \\
\hline UNITED BANKSHS & UBSI US Equity & 1.20 & 6022 & Banks \\
\hline FIRST NIAGARA FI & FNFG US Equity & 1.20 & 6036 & Banks \\
\hline NORTHWEST BANCSH & NWBI US Equity & 1.30 & 6021 & Banks \\
\hline WESTAMERICA BANC & WABC US Equity & 1.30 & 6021 & Banks \\
\hline
\end{tabular}




\begin{tabular}{|c|c|c|c|c|}
\hline PROSPERITY BNCSH & PRSP US Equity & 1.30 & 6022 & Banks \\
\hline CATHAY GENERAL B & CATY US Equity & 1.30 & 6022 & Banks \\
\hline INTL BANCSHARES & IBOC US Equity & 1.40 & 6022 & Banks \\
\hline TRUSTMARK CORP & TRMK US Equity & 1.50 & 6021 & Banks \\
\hline UCBH HOLDINGS & UCBHQ US Equity & 1.50 & 6022 & Banks \\
\hline FIRST MIDWEST/IL & FMBI US Equity & 1.50 & 6021 & Banks \\
\hline FIRST CITIZENS-A & FCNCA US Equity & 1.50 & 6022 & Banks \\
\hline EAST WEST BNCRP & EWBC US Equity & 1.50 & 6022 & Banks \\
\hline SUSQUEHAN BNCSHS & SUSQ US Equity & 1.60 & 6021 & Banks \\
\hline UMB FINANCIAL & UMBF US Equity & 1.60 & 6021 & Banks \\
\hline FIRSTMERIT CORP & FMER US Equity & 1.60 & 6021 & Banks \\
\hline SVB FINANCIAL GR & SIVB US Equity & 1.60 & 6022 & Banks \\
\hline WEBSTER FINL & WBS US Equity & 1.70 & 6021 & Banks \\
\hline WHITNEY HLDG & WTNY US Equity & 1.70 & 6021 & Banks \\
\hline DORAL FINL CORP & DRL US Equity & 1.80 & 6029 & Banks \\
\hline BANCORPSOUTH INC & BXS US Equity & 1.90 & 6022 & Banks \\
\hline FULTON FINANCIAL & FULT US Equity & 1.90 & 6021 & Banks \\
\hline CAN WESTERN BANK & CWB CN Equity & 2.00 & 6021 & Banks \\
\hline ASTORIA FINL & AF US Equity & 2.20 & 6035 & Banks \\
\hline TCF FINL CORP & TCB US Equity & 2.30 & 6021 & Banks \\
\hline VALLEY NATL BANC & VLY US Equity & 2.30 & 6021 & Banks \\
\hline FIRST HORIZON NA & FHN US Equity & 2.30 & 6021 & Banks \\
\hline WASH FED & WFSL US Equity & 2.30 & 6035 & Banks \\
\hline WILMINGTON TRUST & WL US Equity & 2.40 & 6022 & Banks \\
\hline CAPITOL FEDERAL & CFFN US Equity & 2.50 & 6035 & Banks \\
\hline CITY NATL CORP & CYN US Equity & 2.90 & 6021 & Banks \\
\hline BANK OF HAWAII & BOH US Equity & 2.90 & 6022 & Banks \\
\hline POPULAR INC & BPOP US Equity & 3.00 & 6022 & Banks \\
\hline CULLEN/FROST & CFR US Equity & 3.00 & 6021 & Banks \\
\hline COMMERCE BCSHS & CBSH US Equity & 3.20 & 6022 & Banks \\
\hline ASSOC BANC-CORP & ASBC US Equity & 3.40 & 6022 & Banks \\
\hline BOK FINL CORP & BOKF US Equity & 3.60 & 6022 & Banks \\
\hline ZIONS BANCORP & ZION US Equity & 5.00 & 6021 & Banks \\
\hline PEOPLE'S UNITED & PBCT US Equity & 5.40 & 6035 & Banks \\
\hline HUNTINGTON BANC & HBAN US Equity & 5.40 & 6021 & Banks \\
\hline NY COMM BANCORP & NYB US Equity & 5.70 & 6036 & Banks \\
\hline CREDICORP LTD & BAP US Equity & 6.10 & 6029 & Banks \\
\hline AMERICAN CAPITAL & ACAS US Equity & 6.50 & 6159 & Banks \\
\hline COMERICA INC & CMA US Equity & 6.50 & 6021 & Banks \\
\hline MARSHALL \&ILSLEY & MI US Equity & 7.00 & 6022 & Banks \\
\hline HUDSON CITY BNCP & HCBK US Equity & 7.30 & 6036 & Banks \\
\hline SYNOVUS FINL & SNV US Equity & 7.90 & 6021 & Banks \\
\hline
\end{tabular}




\begin{tabular}{|c|c|c|c|c|}
\hline M\&T BANK CORP & MTB US Equity & 9.00 & 6022 & Banks \\
\hline NATL BK CANADA & NA CN Equity & 9.10 & 6029 & Banks \\
\hline KEYCORP & KEY US Equity & 9.10 & 6021 & Banks \\
\hline SLM CORP & SLM US Equity & 9.40 & 6141 & Banks \\
\hline WAMU INC & WAMUQ US Equity & 12.00 & 6035 & Banks \\
\hline FIFTH THIRD BANC & FITB US Equity & 13.00 & 6022 & Banks \\
\hline REGIONS FINANCIA & RF US Equity & 16.00 & 6021 & Banks \\
\hline BB\&T CORP & BBT US Equity & 17.00 & 6021 & Banks \\
\hline NORTHERN TRUST & NTRS US Equity & 17.00 & 6022 & Banks \\
\hline CAPITAL ONE FINA & COF US Equity & 18.00 & 6022 & Banks \\
\hline SUNTRUST BANKS & STI US Equity & 22.00 & 6021 & Banks \\
\hline PNC FINANCIAL SE & PNC US Equity & 22.00 & 6021 & Banks \\
\hline STATE ST CORP & STT US Equity & 31.00 & 6022 & Banks \\
\hline BANK OF MONTREAL & BMO CN Equity & 33.00 & 6021 & Banks \\
\hline CAN IMPL BK COMM & CM CN Equity & 36.00 & 6021 & Banks \\
\hline $\begin{array}{l}\text { TORONTO-DOM } \\
\text { BANK }\end{array}$ & TD CN Equity & 54.00 & 6021 & Banks \\
\hline US BANCORP & USB US Equity & 55.00 & 6021 & Banks \\
\hline BANK OF NOVA SCO & BNS CN Equity & 55.00 & 6029 & Banks \\
\hline BANK NY MELLON & BK US Equity & 56.00 & 6022 & Banks \\
\hline AMERICAN EXPRESS & AXP US Equity & 60.00 & 6141 & Banks \\
\hline ROYAL BANK OF CA & RY CN Equity & 75.00 & 6021 & Banks \\
\hline WELLS FARGO \& CO & WFC US Equity & 100.00 & 6021 & Banks \\
\hline JPMORGAN CHASE & JPM US Equity & 150.00 & 6021 & Banks \\
\hline CITIGROUP INC & C US Equity & 150.00 & 6021 & Banks \\
\hline BANK OF AMERICA & BAC US Equity & 180.00 & 6021 & Banks \\
\hline INTERDIGITAL INC & IDCC US Equity & 1.10 & 6794 & Brokers \\
\hline KNIGHT CAPITAL-A & KCG US Equity & 1.30 & 6211 & Brokers \\
\hline DUNDEE CORP-A & DC/A CN Equity & 1.40 & 6282 & Brokers \\
\hline GAMCO INVESTORS & GBL US Equity & 2.00 & 6211 & Brokers \\
\hline INVESTMENT TECH & ITG US Equity & 2.10 & 6211 & Brokers \\
\hline BAM INVESTMENTS & BNB CN Equity & 2.10 & 6719 & Brokers \\
\hline JEFFERIES GROUP & JEF US Equity & 2.90 & 6211 & Brokers \\
\hline WADDELL \& REED-A & WDR US Equity & 3.10 & 6211 & Brokers \\
\hline RAYMOND JAMES & RJF US Equity & 3.90 & 6211 & Brokers \\
\hline FEDERATED INV-B & FII US Equity & 4.20 & 6282 & Brokers \\
\hline AFFIL MANAGERS & AMG US Equity & 4.60 & 6282 & Brokers \\
\hline JANUS CAPITAL GR & JNS US Equity & 5.50 & 6282 & Brokers \\
\hline EATON VANCE CORP & EV US Equity & 5.90 & 6282 & Brokers \\
\hline SEI INVESTMENTS & SEIC US Equity & 6.30 & 6211 & Brokers \\
\hline ALLIANCEBERNSTEI & AB US Equity & 6.50 & 6282 & Brokers \\
\hline CI FINANCIAL COR & CIX CN Equity & 8.00 & 6722 & Brokers \\
\hline
\end{tabular}




\begin{tabular}{|c|c|c|c|c|}
\hline ICAHN ENTERPRISE & IEP US Equity & 9.10 & 6719 & Brokers \\
\hline TD AMERITRADE HO & AMTD US Equity & 11.00 & 6211 & Brokers \\
\hline LEGG MASON INC & LM US Equity & 12.00 & 6282 & Brokers \\
\hline IGM FINANCIAL IN & IGM CN Equity & 13.00 & 6282 & Brokers \\
\hline T ROWE PRICE GRP & TROW US Equity & 16.00 & 6282 & Brokers \\
\hline BROOKFIELD ASS-A & BAM/A CN Equity & 20.00 & 6719 & Brokers \\
\hline BLACKROCK INC & BLK US Equity & 25.00 & 6282 & Brokers \\
\hline SCHWAB (CHARLES) & SCHW US Equity & 30.00 & 6211 & Brokers \\
\hline FRANKLIN RES INC & BEN US Equity & 31.00 & 6282 & Brokers \\
\hline LEHMAN BROS HLDG & LEHMQ US Equity & 33.00 & 6211 & Brokers \\
\hline MORGAN STANLEY & MS US Equity & 56.00 & 6211 & Brokers \\
\hline GOLDMAN SACHS GP & GS US Equity & 99.00 & 6211 & Brokers \\
\hline RADIAN GROUP INC & RDN US Equity & 0.94 & 6351 & Insurance \\
\hline STATE AUTO FINL & STFC US Equity & 1.10 & 6331 & Insurance \\
\hline HARLEYSVILLE GRP & HGIC US Equity & 1.10 & 6331 & Insurance \\
\hline PMI GROUP INC & PMI US Equity & 1.10 & 6351 & Insurance \\
\hline NAVIGATORS GROUP & NAVG US Equity & 1.10 & 6331 & Insurance \\
\hline SELECT INS GRP & SIGI US Equity & 1.20 & 6331 & Insurance \\
\hline RLI CORP & RLI US Equity & 1.30 & 6331 & Insurance \\
\hline ARGO GROUP INTER & AGII US Equity & 1.30 & 6331 & Insurance \\
\hline PROASSURANCE COR & PRA US Equity & 1.80 & 6331 & Insurance \\
\hline MGIC INVT CORP & MTG US Equity & 1.80 & 6351 & Insurance \\
\hline UNIVERSAL AMERIC & UAM US Equity & 1.90 & 6324 & Insurance \\
\hline DELPHI FINL GRP & DFG US Equity & 1.90 & 6311 & Insurance \\
\hline ARTHUR J GALLAGH & AJG US Equity & 2.20 & 6411 & Insurance \\
\hline MBIA INC & MBI US Equity & 2.30 & 6351 & Insurance \\
\hline HANOVER INSURANC & THG US Equity & 2.40 & 6331 & Insurance \\
\hline STANCORP FINL & SFG US Equity & 2.50 & 6321 & Insurance \\
\hline AMBAC FINL GROUP & ABKFQ US Equity & 2.60 & 6351 & Insurance \\
\hline MERCURY GEN CORP & MCY US Equity & 2.70 & 6331 & Insurance \\
\hline PROTECTIVE LIFE & PL US Equity & 2.90 & 6311 & Insurance \\
\hline WESCO FINANCIAL & WSC US Equity & 2.90 & 6331 & Insurance \\
\hline UNITRIN INC & UTR US Equity & 3.10 & 6331 & Insurance \\
\hline ERIE INDEMNITY-A & ERIE US Equity & 3.10 & 6331 & Insurance \\
\hline AMER NATL INSUR & ANAT US Equity & 3.30 & 6311 & Insurance \\
\hline REINSURANCE GROU & RGA US Equity & 3.30 & 6321 & Insurance \\
\hline AMER FINL GROUP & AFG US Equity & 3.30 & 6331 & Insurance \\
\hline HCC INSURANCE & HCC US Equity & 3.30 & 6331 & Insurance \\
\hline BROWN \& BROWN & BRO US Equity & 3.30 & 6411 & Insurance \\
\hline ALLEGHANY CORP & Y US Equity & 3.30 & 6331 & Insurance \\
\hline IND ALLIANCE INS & IAG CN Equity & 3.40 & 6311 & Insurance \\
\hline OLD REPUB INTL & ORI US Equity & 3.60 & 6351 & Insurance \\
\hline
\end{tabular}




\begin{tabular}{|c|c|c|c|c|}
\hline RENAISSANCERE & RNR US Equity & 4.20 & 6331 & Insurance \\
\hline PARTNERRE LTD & PRE US Equity & 4.50 & 6331 & Insurance \\
\hline ARCH CAPITAL GRP & ACGL US Equity & 4.70 & 6331 & Insurance \\
\hline TRANSATLANTIC HL & TRH US Equity & 4.80 & 6331 & Insurance \\
\hline MARKEL CORP & MKL US Equity & 4.90 & 6331 & Insurance \\
\hline FAIRFAX FINL HLD & FFH CN Equity & 5.10 & 6331 & Insurance \\
\hline HEALTH NET INC & HNT US Equity & 5.30 & 6324 & Insurance \\
\hline WR BERKLEY CORP & WRB US Equity & 5.40 & 6331 & Insurance \\
\hline WHITE MOUNTAINS & WTM US Equity & 5.40 & 6331 & Insurance \\
\hline TORCHMARK CORP & TMK US Equity & 5.60 & 6311 & Insurance \\
\hline EVEREST RE GROUP & RE US Equity & 6.30 & 6331 & Insurance \\
\hline CINCINNATI FIN & CINF US Equity & 6.60 & 6331 & Insurance \\
\hline UNUM GROUP & UNM US Equity & 8.60 & 6321 & Insurance \\
\hline XL GROUP PLC & XL US Equity & 9.00 & 6351 & Insurance \\
\hline CNA FINL CORP & CNA US Equity & 9.20 & 6331 & Insurance \\
\hline COVENTRY HEALTH & CVH US Equity & 9.20 & 6324 & Insurance \\
\hline HUMANA INC & HUM US Equity & 13.00 & 6324 & Insurance \\
\hline PROGRESSIVE CORP & PGR US Equity & 13.00 & 6331 & Insurance \\
\hline $\begin{array}{l}\text { MARSH \& } \\
\text { MCLENNAN }\end{array}$ & MMC US Equity & 14.00 & 6411 & Insurance \\
\hline AON CORP & AON US Equity & 15.00 & 6411 & Insurance \\
\hline CIGNA CORP & CI US Equity & 15.00 & 6324 & Insurance \\
\hline LINCOLN NATL CRP & LNC US Equity & 15.00 & 6311 & Insurance \\
\hline ACE LTD & ACE US Equity & 20.00 & 6331 & Insurance \\
\hline CHUBB CORP & CB US Equity & 20.00 & 6331 & Insurance \\
\hline LOEWS CORP & L US Equity & 27.00 & 6331 & Insurance \\
\hline HARTFORD FINL SV & HIG US Equity & 27.00 & 6331 & Insurance \\
\hline ALLSTATE CORP & ALL US Equity & 29.00 & 6331 & Insurance \\
\hline AFLAC INC & AFL US Equity & 30.00 & 6321 & Insurance \\
\hline SUN LIFE FINANCI & SLF CN Equity & 32.00 & 6321 & Insurance \\
\hline GREAT-WEST LIFEC & GWO CN Equity & 32.00 & 6311 & Insurance \\
\hline TRAVELERS COS IN & TRV US Equity & 34.00 & 6331 & Insurance \\
\hline METLIFE INC & MET US Equity & 45.00 & 6311 & Insurance \\
\hline MANULIFE FIN & MFC CN Equity & 61.00 & 6321 & Insurance \\
\hline UNITEDHEALTH GRP & UNH US Equity & 73.00 & 6324 & Insurance \\
\hline AMERICAN INTERNA & AIG US Equity & 150.00 & 6331 & Insurance \\
\hline BERKSHIRE HATH-A & BRK/A US Equity & 220.00 & 6331 & Insurance \\
\hline LEXINGTON REALTY & LXP US Equity & 0.89 & 6798 & Real Estate \\
\hline STEWART ENTERP-A & STEI US Equity & 0.89 & 6553 & Real Estate \\
\hline COMINAR REA-TR U & CUF-U CN Equity & 0.93 & 6798 & Real Estate \\
\hline EASTGROUP PROP & EGP US Equity & 1.00 & 6798 & Real Estate \\
\hline COLONIAL PROPS & CLP US Equity & 1.10 & 6798 & Real Estate \\
\hline
\end{tabular}




\begin{tabular}{|c|c|c|c|c|}
\hline CAN APARTMENT & CAR-U CN Equity & 1.10 & 6798 & Real Estate \\
\hline FELCOR LODGING & FCH US Equity & 1.10 & 6798 & Real Estate \\
\hline PS BUSINESS PARK & PSB US Equity & 1.10 & 6798 & Real Estate \\
\hline OMEGA & & & & \\
\hline HEALTHCARE & OHI US Equity & 1.10 & 6798 & Real Estate \\
\hline MID-AMERICA APAR & MAA US Equity & 1.10 & 6798 & Real Estate \\
\hline COUSINS PROP & CUZ US Equity & 1.10 & 6798 & Real Estate \\
\hline MFA FINANCIAL & MFA US Equity & 1.10 & 6798 & Real Estate \\
\hline PENN REIT & PEI US Equity & 1.20 & 6798 & Real Estate \\
\hline TANGER FACTORY & SKT US Equity & 1.20 & 6798 & Real Estate \\
\hline LASALLE HOTEL PR & LHO US Equity & 1.30 & 6798 & Real Estate \\
\hline HEALTHCARE RLTY & HR US Equity & 1.30 & 6798 & Real Estate \\
\hline WP CAREY \& CO & WPC US Equity & 1.30 & 6500 & Real Estate \\
\hline ENTERTAINMENT PR & EPR US Equity & 1.40 & 6798 & Real Estate \\
\hline HOME PROPERTIES & HME US Equity & 1.50 & 6798 & Real Estate \\
\hline WASHINGTON REIT & WRE US Equity & 1.50 & 6798 & Real Estate \\
\hline CORP OFFICE PROP & OFC US Equity & 1.50 & 6798 & Real Estate \\
\hline FIRST IND REALTY & FR US Equity & 1.50 & 6798 & Real Estate \\
\hline POST PROPERTIES & PPS US Equity & 1.50 & 6798 & Real Estate \\
\hline BRANDYWINE RLTY & BDN US Equity & 1.60 & 6798 & Real Estate \\
\hline CBL \& ASSOC PROP & CBL US Equity & 1.60 & 6798 & Real Estate \\
\hline HIGHWOODS PROP & HIW US Equity & 1.70 & 6798 & Real Estate \\
\hline EQUITY ONE INC & EQY US Equity & 1.70 & 6798 & Real Estate \\
\hline NATIONAL RETAIL & NNN US Equity & 1.70 & 6798 & Real Estate \\
\hline $\begin{array}{l}\text { COMMONWEALTH } \\
\text { REI }\end{array}$ & CWH US Equity & 1.70 & 6798 & Real Estate \\
\hline CAN REAL ESTATE & REF-U CN Equity & 1.80 & 6798 & Real Estate \\
\hline ALEXANDER'S INC & ALX US Equity & 1.80 & 6798 & Real Estate \\
\hline KILROY REALTY & KRC US Equity & 1.80 & 6798 & Real Estate \\
\hline FIRST CAP REALTY & FCR CN Equity & 1.90 & 6512 & Real Estate \\
\hline SENIOR HOUSING & SNH US Equity & 2.00 & 6798 & Real Estate \\
\hline BRE PROPERTIES & BRE US Equity & 2.10 & 6798 & Real Estate \\
\hline MACK-CALI REALTY & CLI US Equity & 2.20 & 6798 & Real Estate \\
\hline ESSEX PROPERTY & ESS US Equity & 2.40 & 6798 & Real Estate \\
\hline H\&R REAL-REIT UT & HR-U CN Equity & 2.60 & 6798 & Real Estate \\
\hline LIBERTY PROP & LRY US Equity & 2.60 & 6798 & Real Estate \\
\hline ST JOE CO & JOE US Equity & 2.60 & 6552 & Real Estate \\
\hline WEINGARTEN RLTY & WRI US Equity & 2.70 & 6798 & Real Estate \\
\hline REALTY INCOME & O US Equity & 2.70 & 6798 & Real Estate \\
\hline UDR INC & UDR US Equity & 2.90 & 6798 & Real Estate \\
\hline NATIONWIDE HLTH & NHP US Equity & 3.00 & 6798 & Real Estate \\
\hline HOSPITALITY PROP & HPT US Equity & 3.00 & 6798 & Real Estate \\
\hline
\end{tabular}




\begin{tabular}{|c|c|c|c|c|}
\hline ALEXANDRIA REAL & ARE US Equity & 3.20 & 6798 & Real Estate \\
\hline CAMDEN PROP TR & CPT US Equity & 3.30 & 6798 & Real Estate \\
\hline APARTMENT INVEST & AIV US Equity & 3.30 & 6798 & Real Estate \\
\hline ISTAR FINANCIAL & SFI US Equity & 3.50 & 6798 & Real Estate \\
\hline RAYONIER INC & RYN US Equity & 3.70 & 6798 & Real Estate \\
\hline DUKE REALTY CORP & DRE US Equity & 3.80 & 6798 & Real Estate \\
\hline HEALTH CARE REIT & HCN US Equity & 3.80 & 6798 & Real Estate \\
\hline REGENCY CENTERS & REG US Equity & 4.50 & 6798 & Real Estate \\
\hline DEVELOPERS DIVER & DDR US Equity & 4.60 & 6798 & Real Estate \\
\hline RIOCAN REIT & REI-U CN Equity & 4.60 & 6798 & Real Estate \\
\hline FED REALTY INVS & FRT US Equity & 4.80 & 6798 & Real Estate \\
\hline MACERICH CO & MAC US Equity & 5.10 & 6798 & Real Estate \\
\hline SL GREEN REALTY & SLG US Equity & 5.50 & 6798 & Real Estate \\
\hline AMB PROPERTY & AMB US Equity & 5.70 & 6798 & Real Estate \\
\hline FOREST CITY -A & FCE/A US Equity & 6.20 & 6512 & Real Estate \\
\hline PLUM CREEK TIMBR & PCL US Equity & 7.30 & 6798 & Real Estate \\
\hline $\begin{array}{l}\text { AVALONBAY } \\
\text { COMMUN }\end{array}$ & AVB US Equity & 7.30 & 6798 & Real Estate \\
\hline ANNALY CAPITAL M & NLY US Equity & 7.30 & 6798 & Real Estate \\
\hline HCP INC & HCP US Equity & 7.50 & 6798 & Real Estate \\
\hline BROOKFIELD OFFIC & BPO CN Equity & 7.60 & 6510 & Real Estate \\
\hline HOST HOTELS \& RE & HST US Equity & 8.90 & 6798 & Real Estate \\
\hline KIMCO REALTY & KIM US Equity & 9.20 & 6798 & Real Estate \\
\hline EQUITY RESIDENTI & EQR US Equity & 9.80 & 6798 & Real Estate \\
\hline GENERAL GROWTH P & GGP US Equity & 10.00 & 6798 & Real Estate \\
\hline BOSTON PROPERTIE & BXP US Equity & 11.00 & 6798 & Real Estate \\
\hline PUBLIC STORAGE & PSA US Equity & 12.00 & 6798 & Real Estate \\
\hline VORNADO RLTY TST & VNO US Equity & 13.00 & 6798 & Real Estate \\
\hline PROLOGIS & PLD US Equity & 16.00 & 6798 & Real Estate \\
\hline SIMON PROPERTY & SPG US Equity & 19.00 & 6798 & Real Estate \\
\hline
\end{tabular}


Appendix 2. Additional Graphs

All graphs (author'scalculations based on data from Bloomberg)
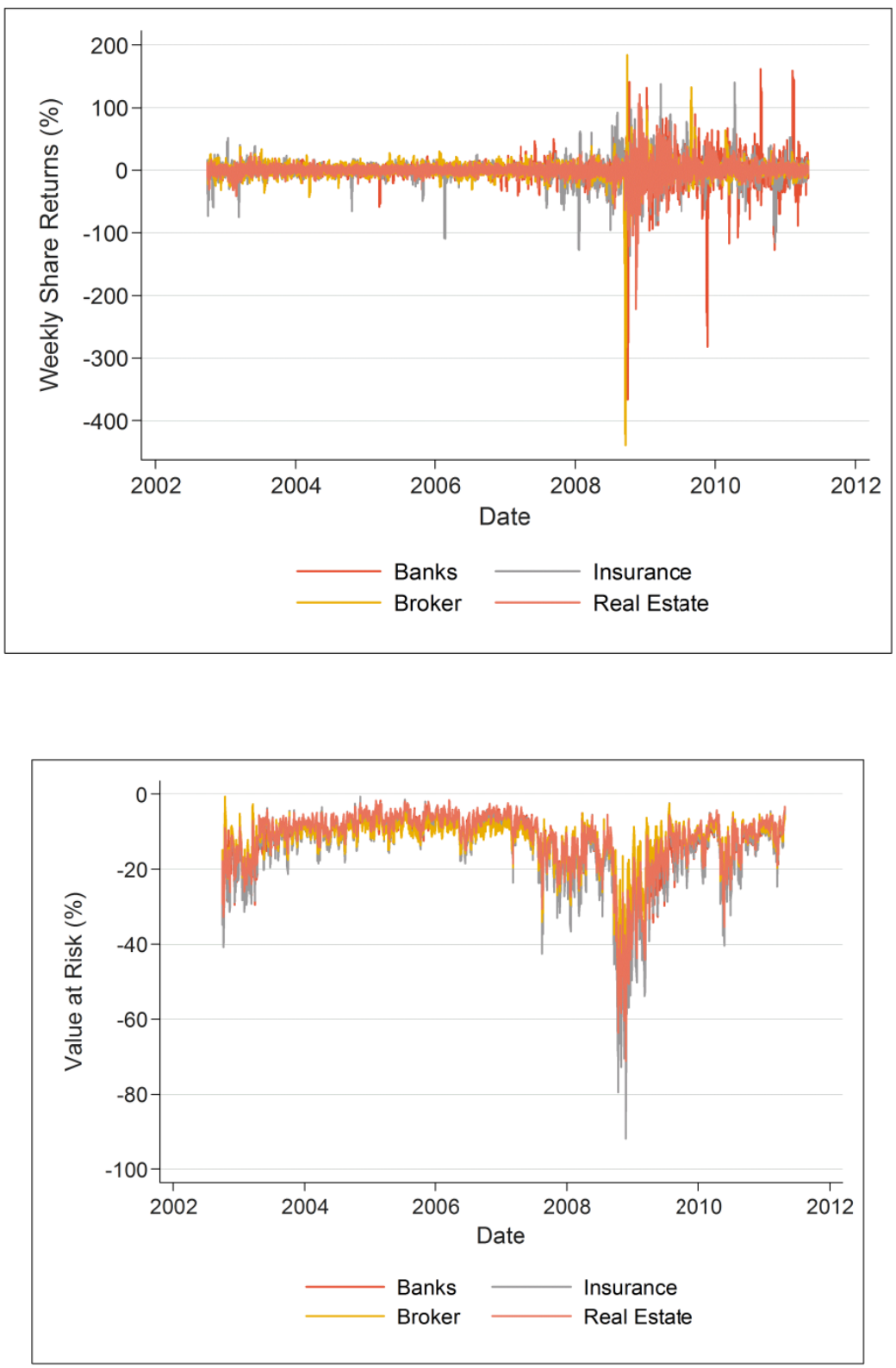

Figure 1. Firm-wise weekly share return and value at risk (1\%) 


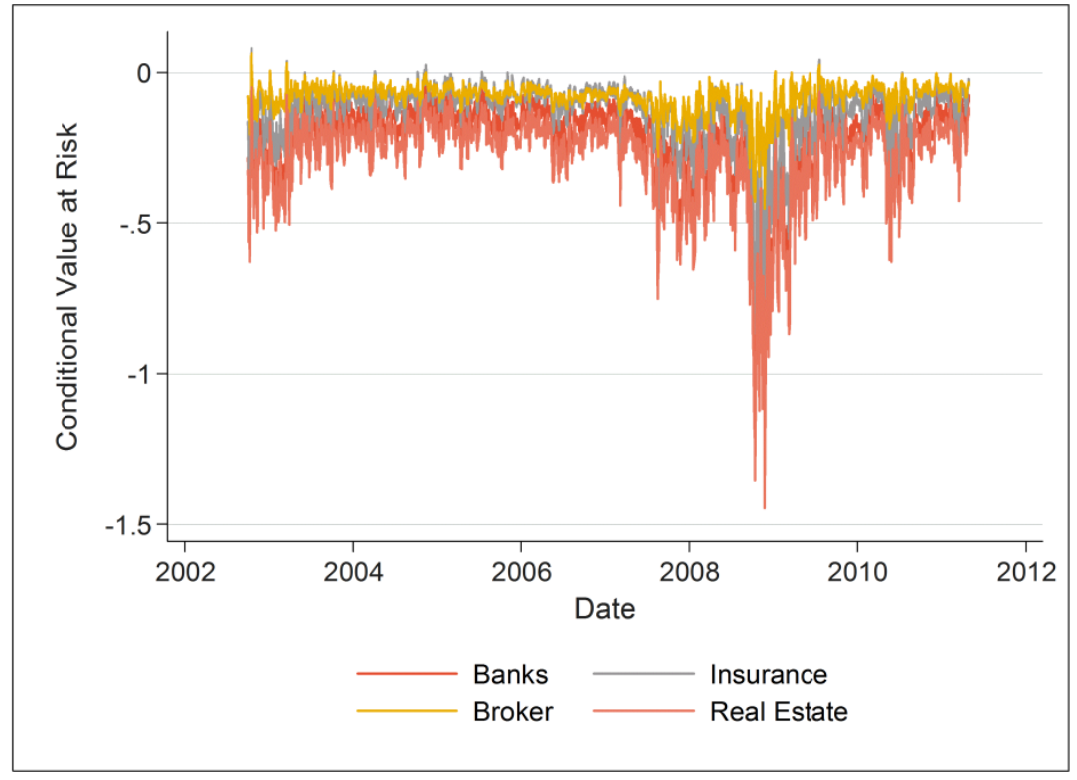

Figure 2. CoVaR of individual firms on respective industries

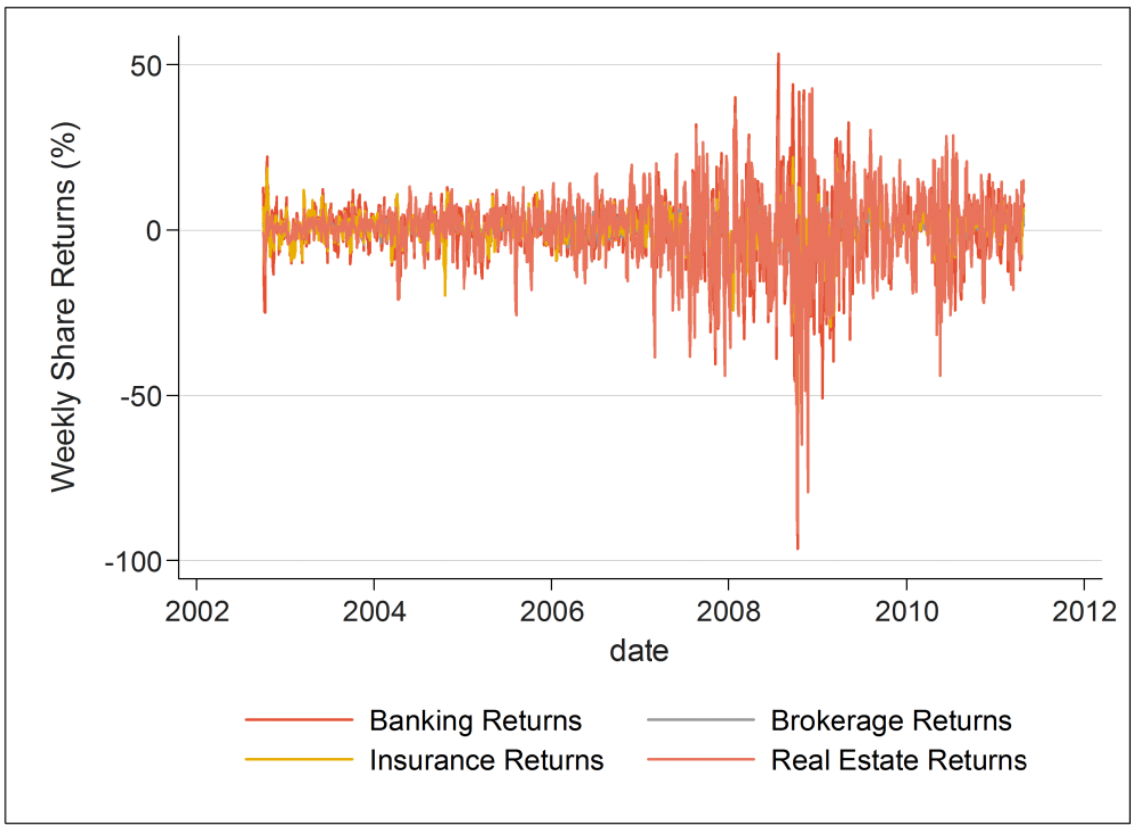




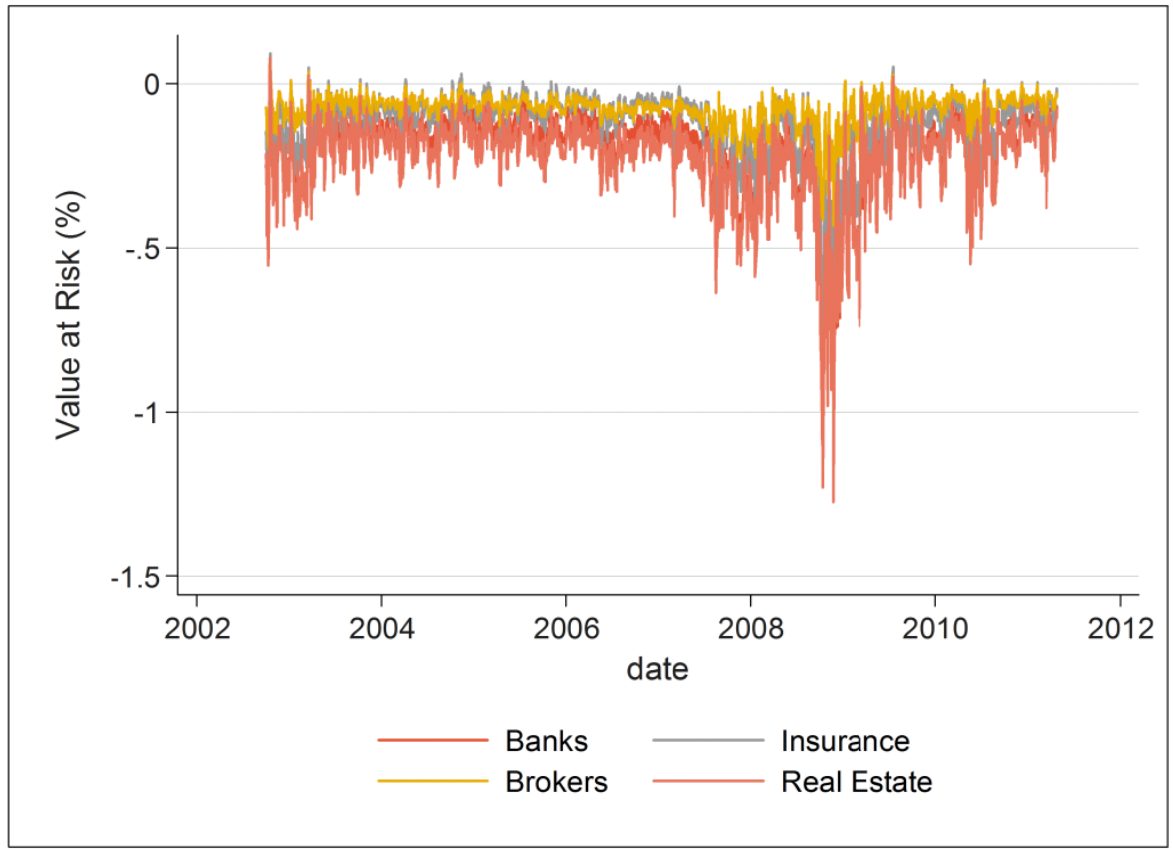

Figure 3. Industry interlinkages: sector-wise weekly share return and value at risk (1\%)

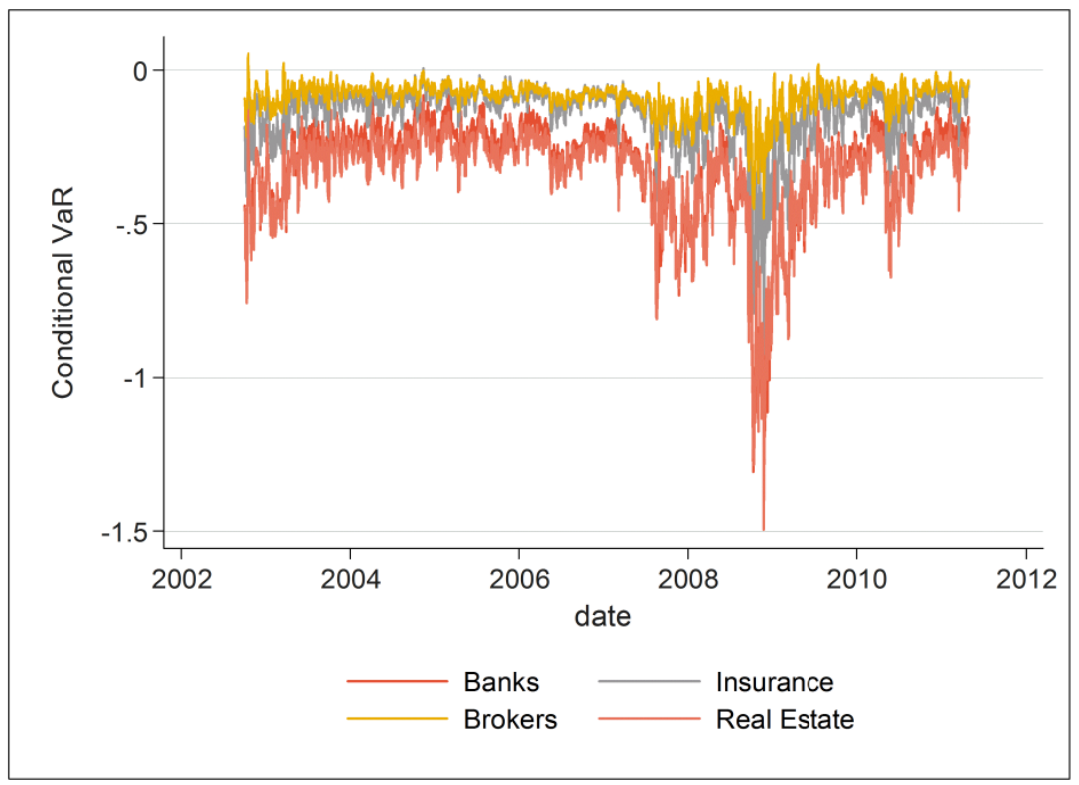

Source of distress-Banking sector 
International Finance and Banking ISSN 2374-2089

2016, Vol. 3, No. 1

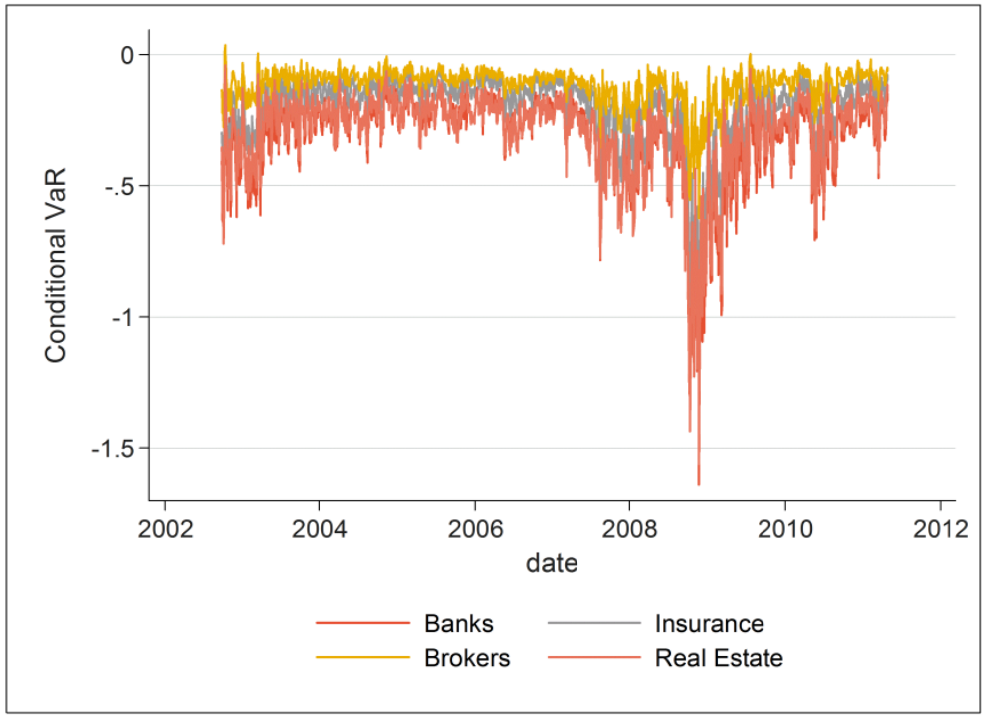

Source of distress - Insurance sector

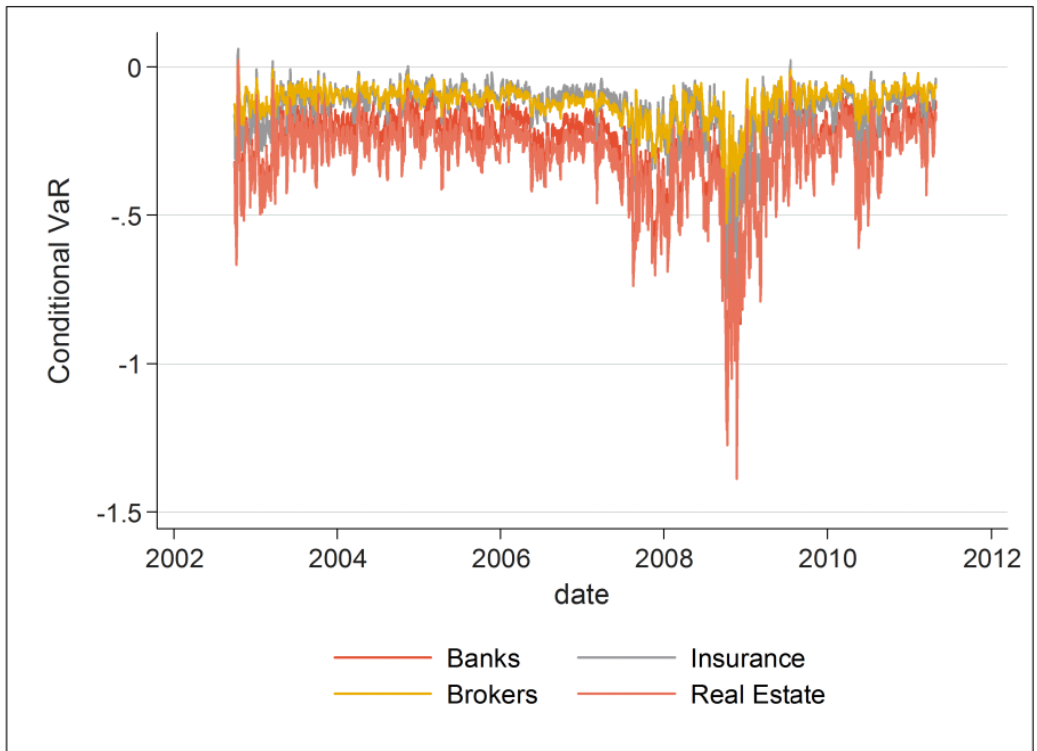

Source of distress-Brokerage sector 


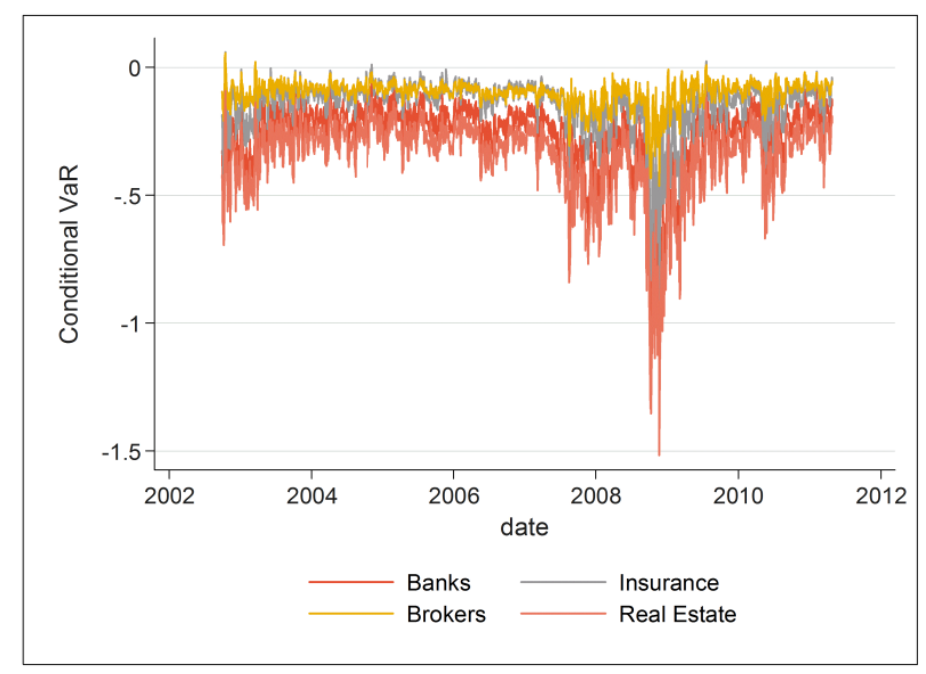

Source of distress—-Real estate sector

Figure 4. Industry interlinkages: conditional VaR

\section{Notes}

Note 1. Explained below.

Note 2. See Appendix 1 for sector mapping and companies under each sample.

Note 3. See detailed description of all codes and companies within each sector in Appendix 1.

\section{Copyright Disclaimer}

Copyright for this article is retained by the author(s), with first publication rights granted to the journal.

This is an open-access article distributed under the terms and conditions of the Creative Commons Attribution license (http://creativecommons.org/licenses/by/3.0/). 